\title{
الإجراءات العملية التي تطبق بها هعايير الجودة في المؤسسات التعليمية
}

\author{
إعلاد \\ ه.عبدالسلام مهنا فريوات
}

مجلة بحوث التربية النوعية - جامعة المنصورة

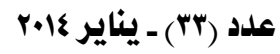




\section{الإجراءات العملية التي تطبق بها هعايير الجودة في المؤسسات التعليمية}

إعداد

د. د. دبدالسلاممهنا فيوانس

يتضضمن هـذا البـث المشكلة وأهــافها، والأدبيـات المتعلقلة بـالجودة، ثم الآليـة الـتي تطبـق بها

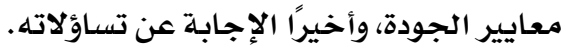

مقدهـة

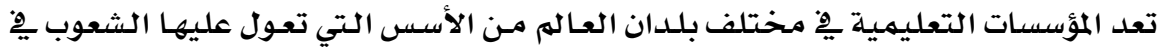

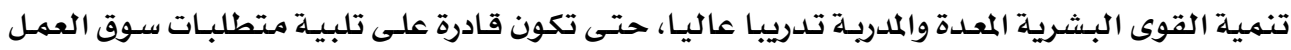

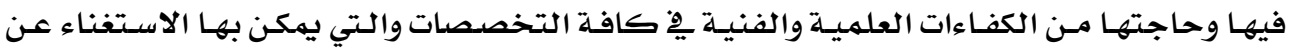

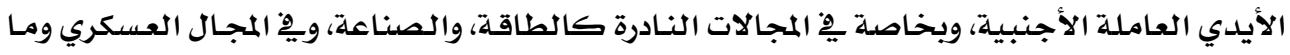

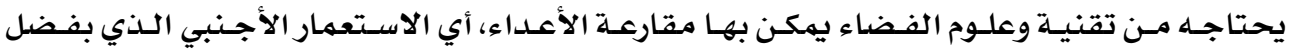

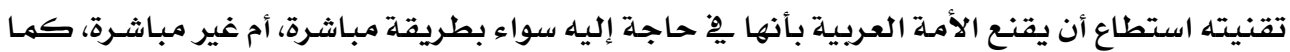

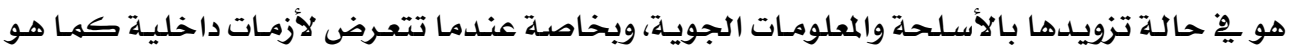

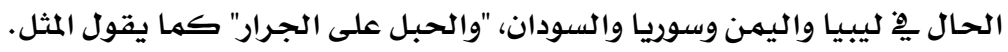

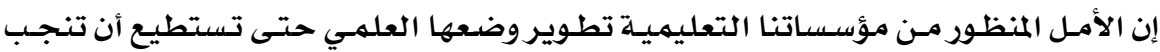

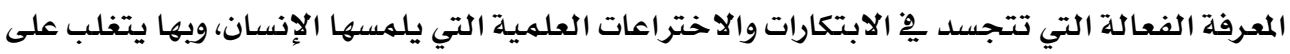

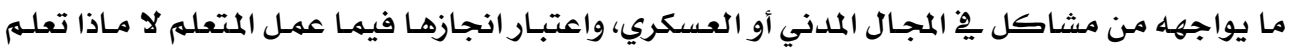

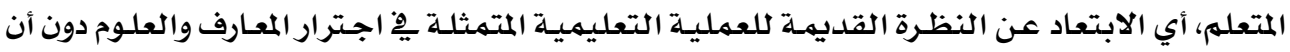

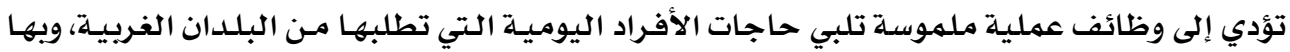

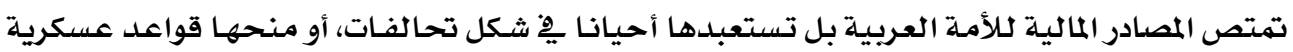
على جزء من أراضيها الزراعية والأمنية.

لهذا أصبـحت المطالبة بتحسين العملية التعليمية الشغل الشاغل لرجـال التربيـة والسياسة،

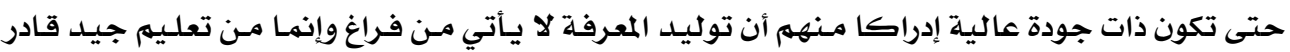

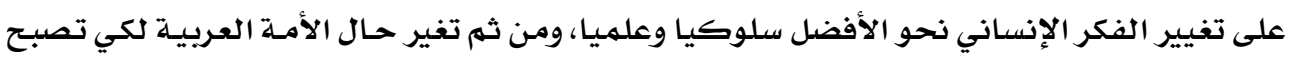

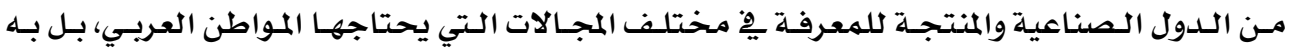

$$
\text { تستيقظ لكل المآرب الغربية. }
$$

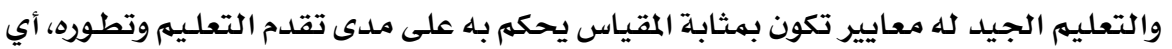

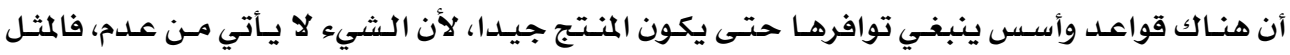


العربي يقول: أعطي الأرض تعطيك، وتؤكد ذلك نظرية (الجشتالت) فِّ مبـدأها "الأرض والشكلية"

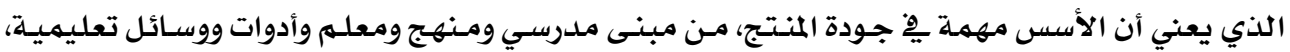

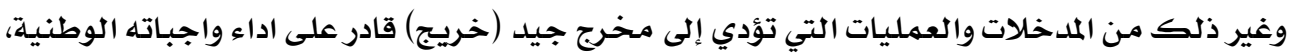

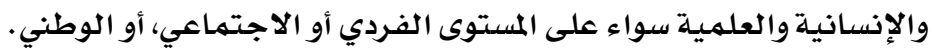

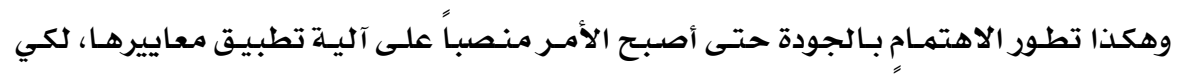

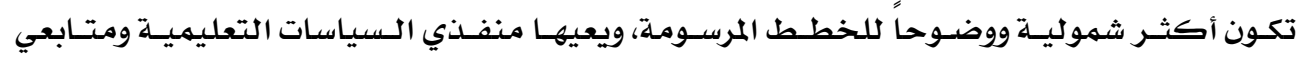

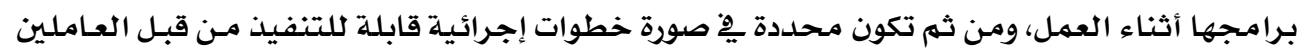

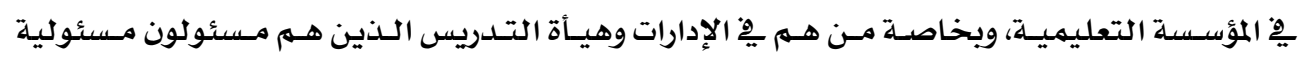

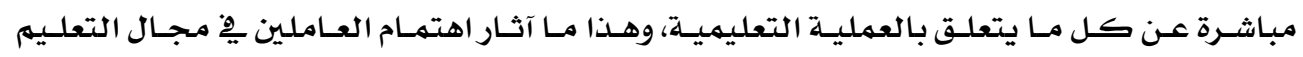

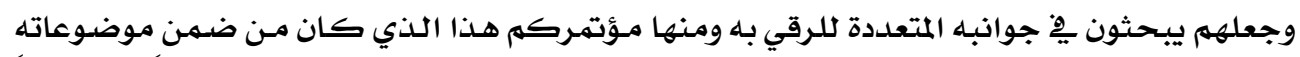

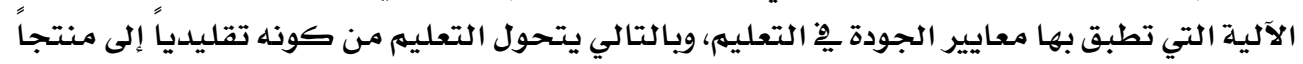

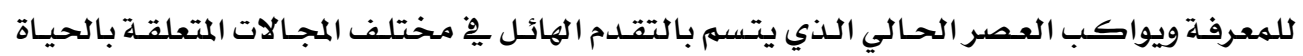

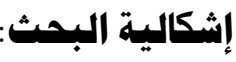

انبثقت إثكالية هذا البحث من اهتمام أبناء الوطن العربي بجودة التعليم، وبخاصة مـن هـم

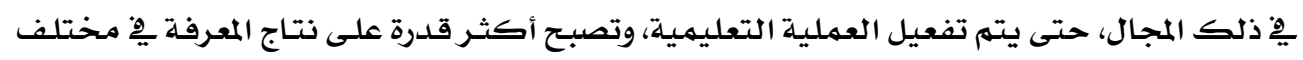

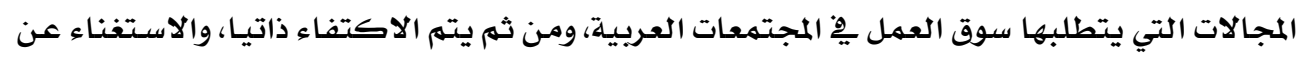

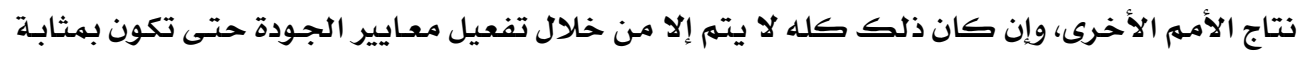

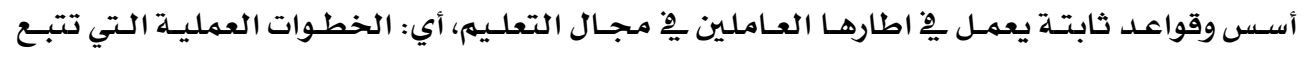

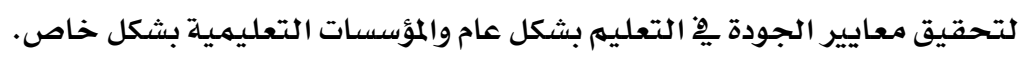
ولهذا تتحدد إشكالية هذا البحث بالتساؤلات الآتية:

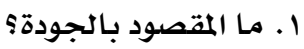

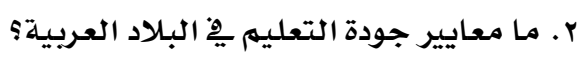

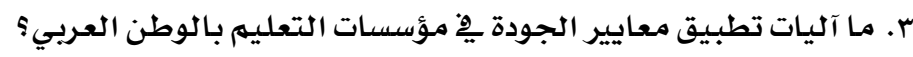

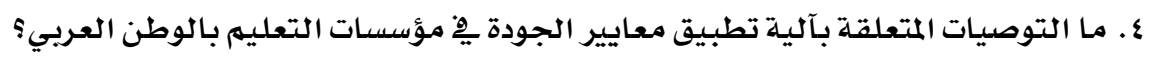

أهمية البحث: ما التوصيات

تكمن أهمية هذا البحث يِّ الآتي:

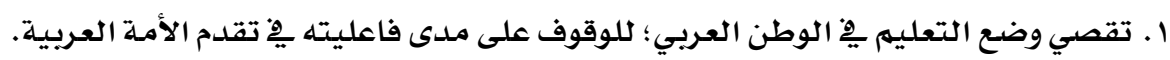

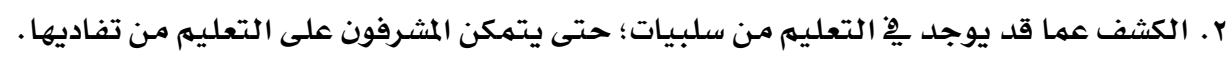

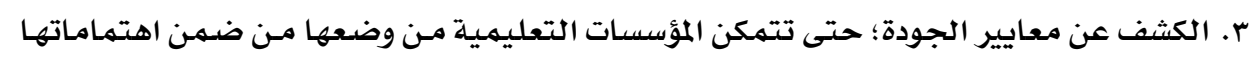
أثناء تأديتها للعملية التعليمية. 
ع. دعوة المهتمـين بالعملية التعليمية، إلى التركيز على جانب الأداء يِّ التعليه، الذي يكون هـدفا

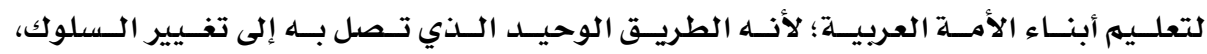

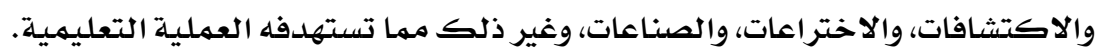

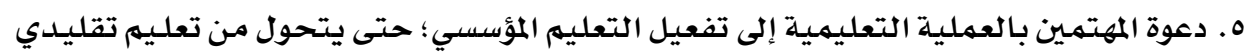

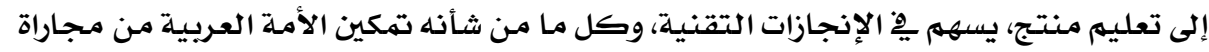

$$
\text { العصر. }
$$

1. إثارة المهتمـين بالعملية التعليمية، بأهميـة النشاط التعليمي فِ المؤسسـات التعليميـة؛ باعتبـاره

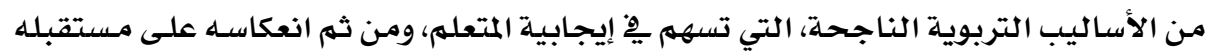

$$
\text { العملي. }
$$

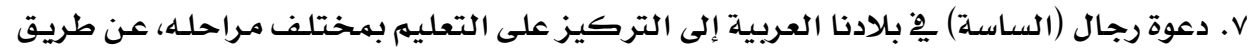

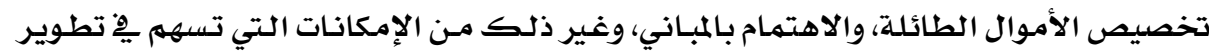

$$
\text { الجامعات العربية. }
$$

^. الاهتمام بعضو هيأة التدريس، وتنشيطه باستمـرار، عن طريق الدورات والنـدوات، والمؤتمـرات ...

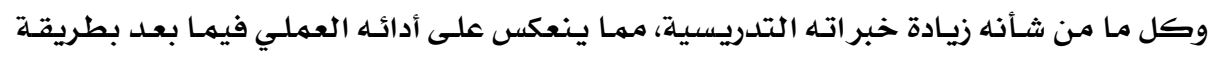

$$
\text { مباشرة أو غير مباشرة. }
$$

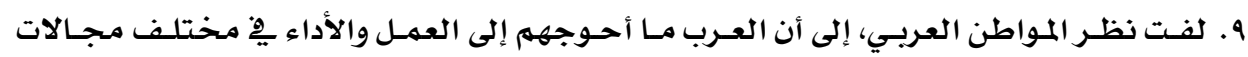

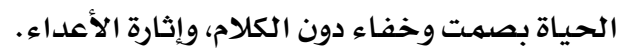

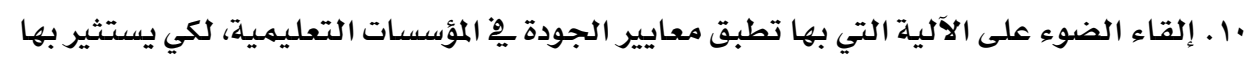
العاملين فِّ مجال التربية والتعليه.

اعتمـد هـذا البحـث على المنهج الوصفي، على اعتبـار أنها أنسب المنـاهج التي تحقق أهـداف

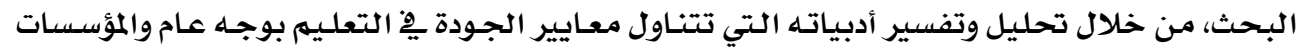

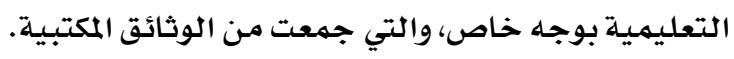

تناول هذا البحث النظري جودة التعليهم يِّ المؤسسات التعليمية بالوطن العربي من خلال:

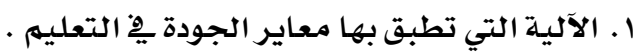

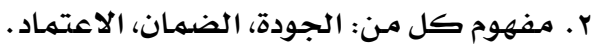

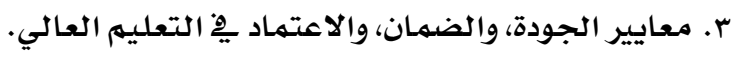
ع. الأساليب التي بها تتحقق جودة التعليم العالي. 


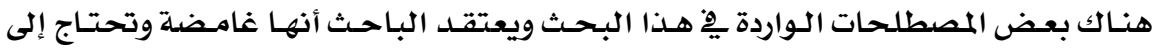
التوضيح وهي:

ا ـ فاعليـة نظام التعليم العـالي: تعـرف فاعليـة نظـام التعليهم العـالي بأنها مـدى تحقيق أهـداف

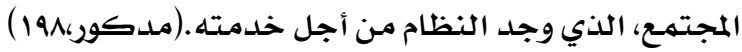

r. جودة التعليم : "وتعني الحكم على مستوى تحقيق الأهـداف وقيمـة هـذا الإنجـاز، ويرتبط هـذا

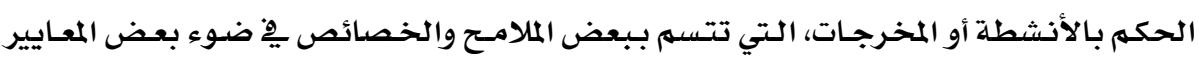

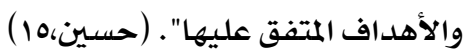

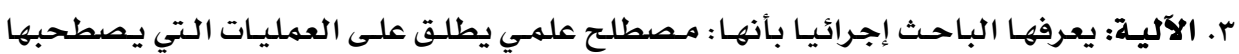

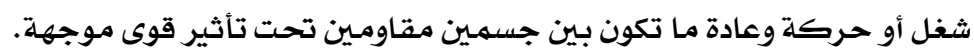
ع. المؤسسة التعليمية: ويعرفها الباحث بأنها " المكان الذي يتعلهم فيه المتعلهم منذ التحاقه بالتعليم التهائ

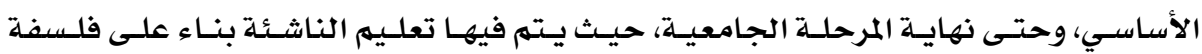

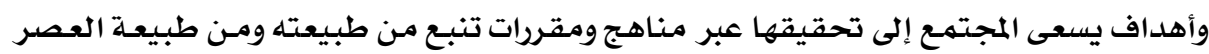

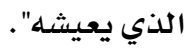

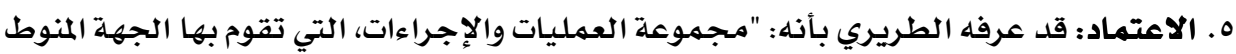

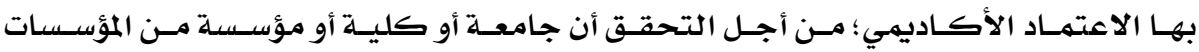

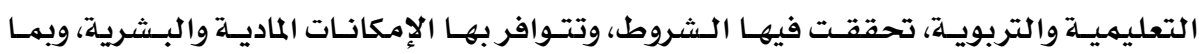

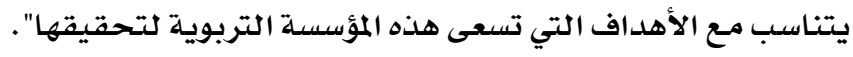

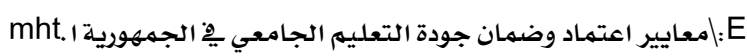

تعتبر أدبيات البحث مهمة يِّ البحوث المكتبية، ولهذا قسمت أدبيات البحث إلى قسمـين همـا:

\section{أولا. الدراسات السابقة التي اهتمت بالجودة ومعاييرها وكيفية تطبيقها:}

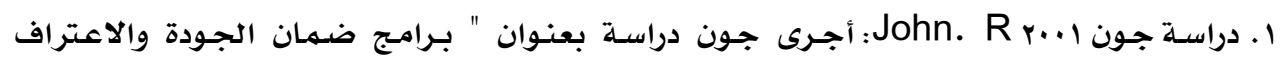

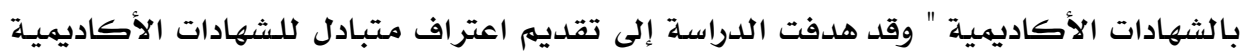

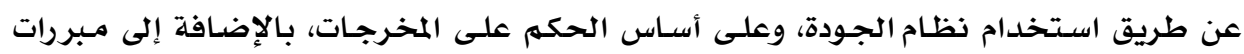

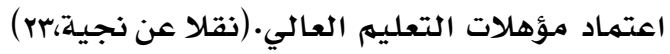

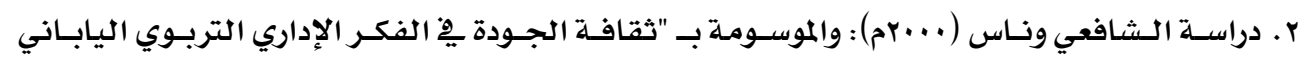

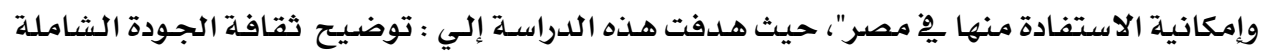

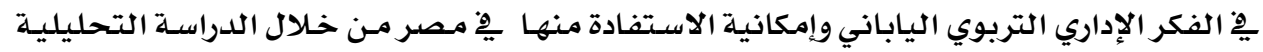




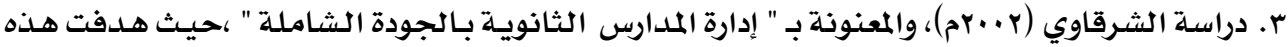

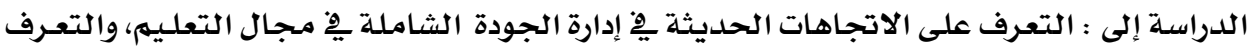

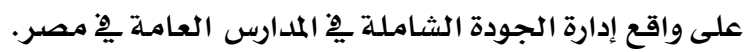

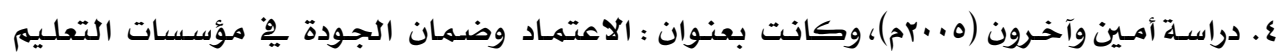

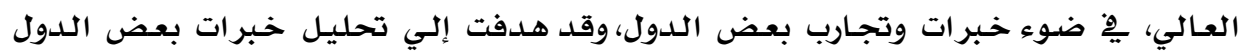

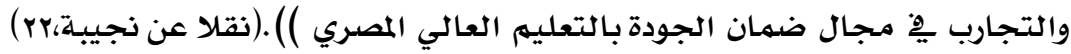

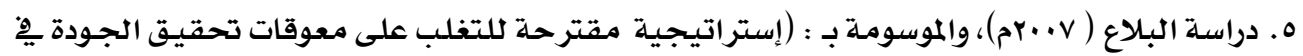

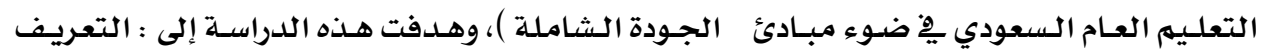

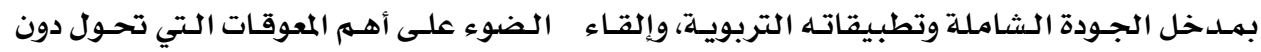

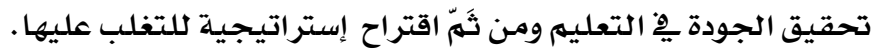

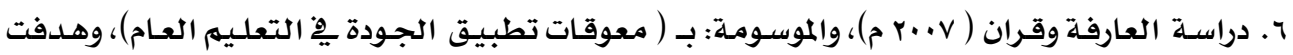

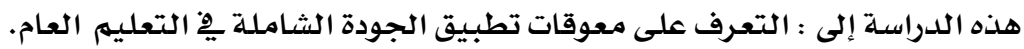

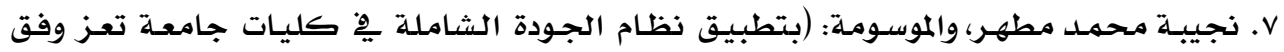
معايير المنظمة الدولية للمواصفات والمعايير من وجهة نظر العمداء ونوابهم ورؤساء الأقسام).

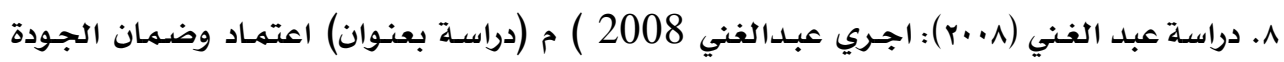

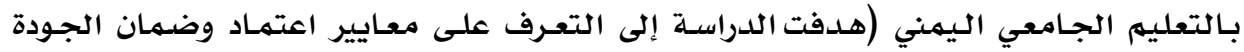

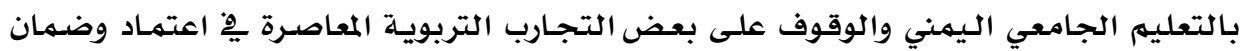

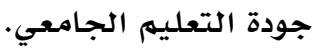
"عبد الغني محمد عبده سعيد 2004 ) اعتماد وضمان الجودة بـالتعليم الجامعي اليمني رسالة ماجستير غير منشورة 2008 م".

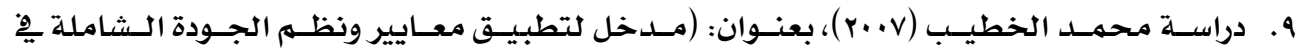

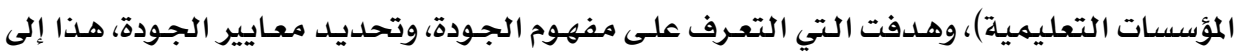

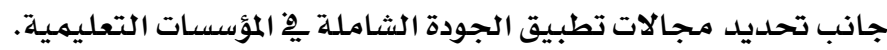

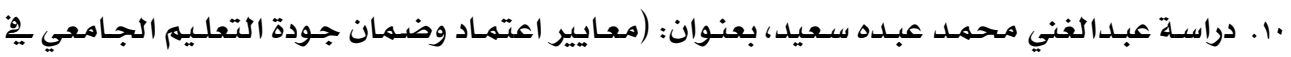

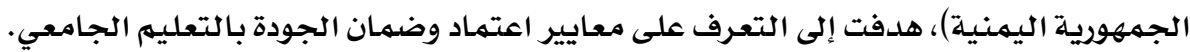

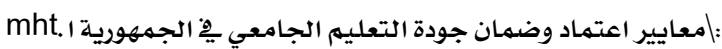

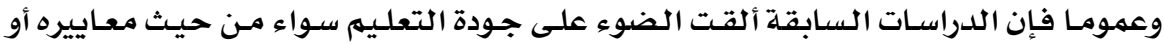

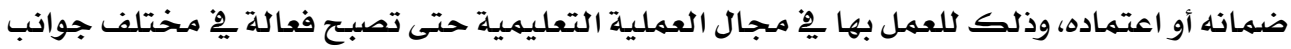

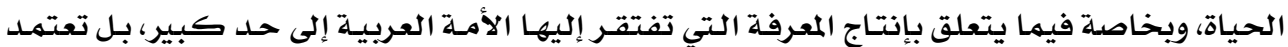
فيها على الأمهم الاخرى. 
ثانيا. الخلفيـة التي ترتبط بها آليـة تطبيق معـايير الجـودة يِّ المؤسسـات التعليميـة بـالوطن

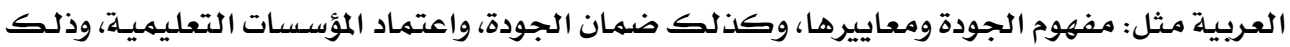

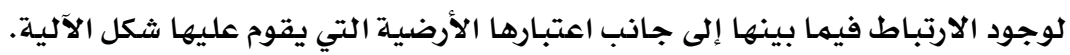

المقصود بالجودة:

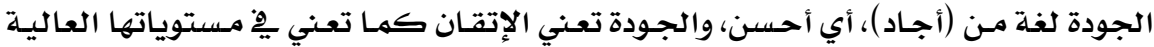

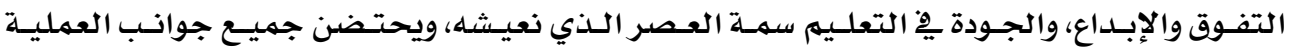

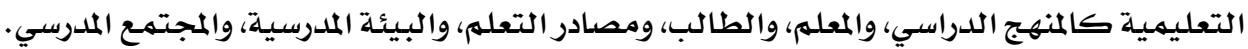

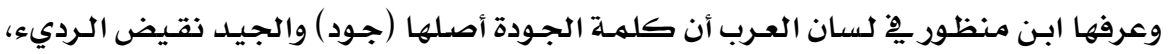

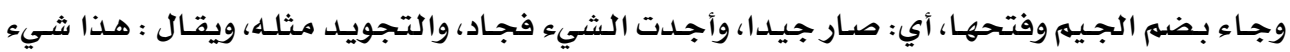

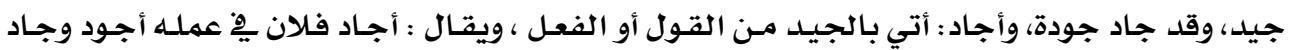

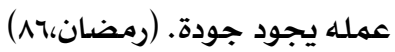

\section{وعرفت الجودة اصطلاحاً بعدة تعريفات، منها ما يأتي: لئي}

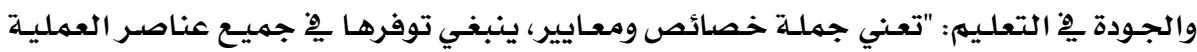

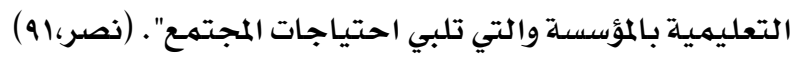

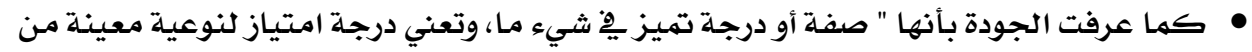

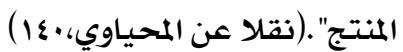

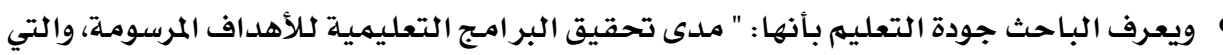

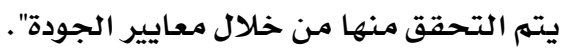

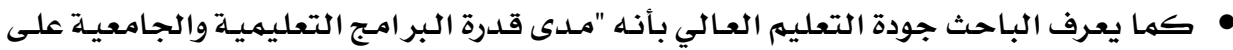

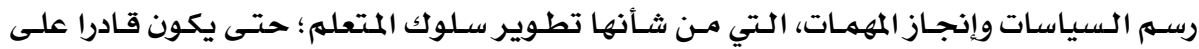

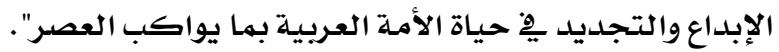

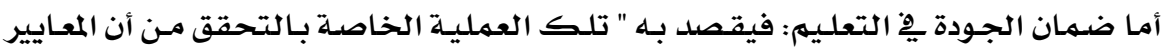

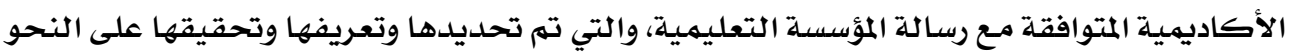

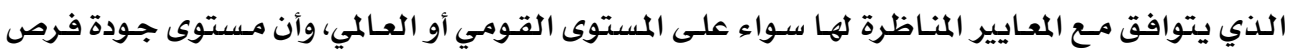

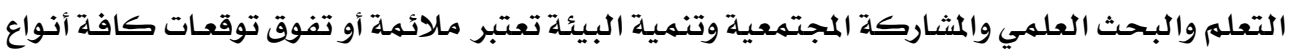

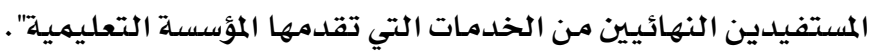
www.alzahraa.ibda3.org8/11/2011

$$
\text { أي: أن يكون لـدي المؤسسـة الوسـائل التي تضمن، مـن خلالها أن تكون الضوابط المنشورة }
$$

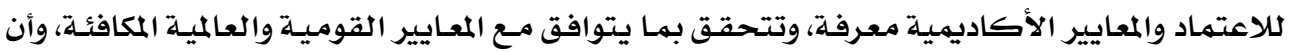

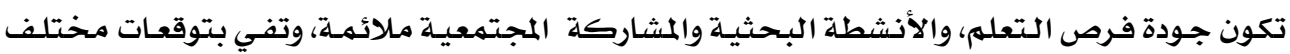
أنواع المستفيدين. 


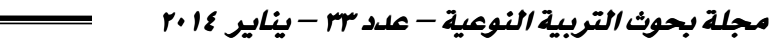

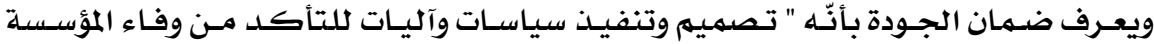

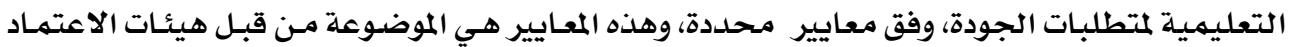
الأكاديهي". www.furat.alwehda.gov.sy8/11/2011 وللتأكد من جودة التعليم فإن الأمر يتطلب اتخاذ الإجراءات الآتية:

$$
\text { 1 أ أ. التقييم والمتابعة مؤسسات التعليم العالي. }
$$

الاعتماد:

جـاء اهتمـام هـذه الورقـة بالاعتمـاد، لأنه يـرتبط بـالجودة إلى حسد كبير، والـذي يتضـح مـن خلال ما يأتي:

$$
\text { مفهوم الاعتماد : الاعتماد لغة يعنى: "الثقة"، واعتمد الشيء، أي: وافق عليه. }
$$

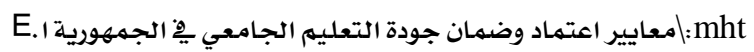

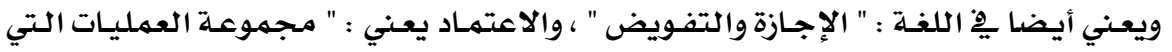

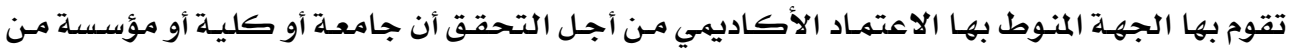

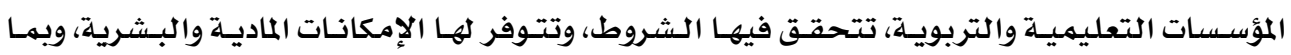

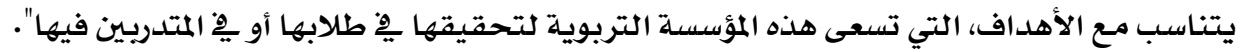
sharia.kuniv.edu.kw/index.php?option=com_content\& view=article\&id=397\&Itemid=252.

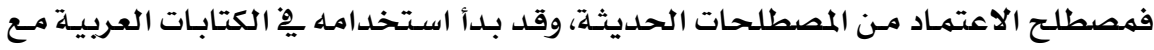

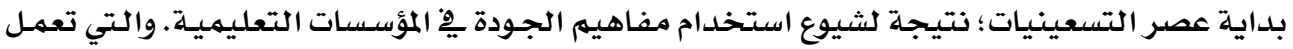

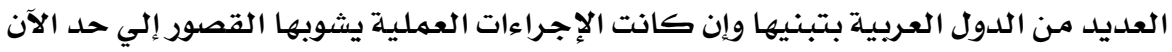
وهناك تعريفات كثيرة كلاعتماد الأكاديهي والمؤسسي، منها ما يأتي:

عرفه محمد عطوة بأنه: "عمليـة تقويم واعتراف بالمؤسسة التعليميـة، وبرنامجها التها الدراسي

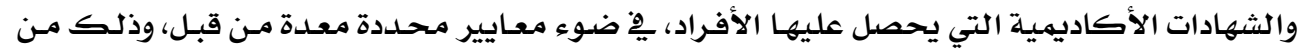

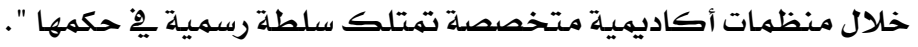

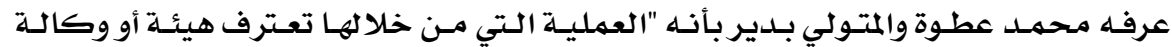

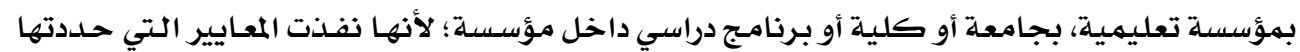
من قبل". 
ولهـذا يقصد بالاعتمـاد: الاعتراف الرسمسي بأهليـة المؤسسـة التعليميـة لأداء مهامها، وأنها

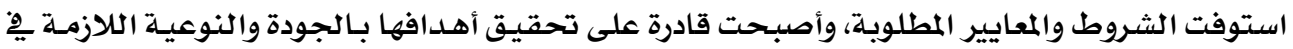

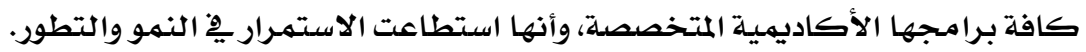

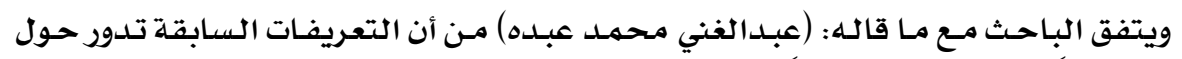

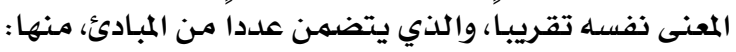

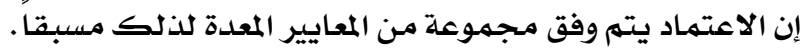

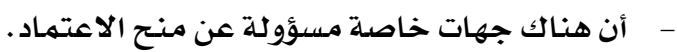

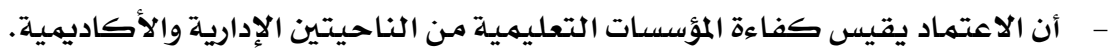

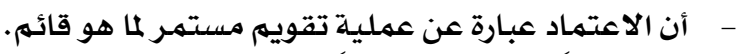

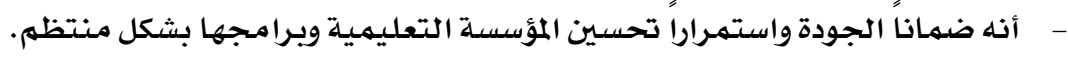

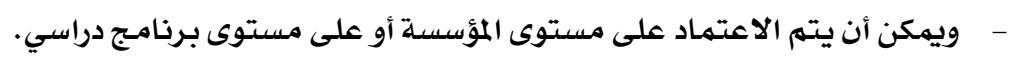

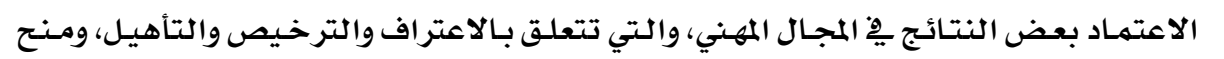
شهادة الجودة للمؤسسة.

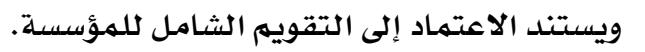
فالاعتهـاد يضمن للمؤسسـات التعليميـة الحفـاظ على سمعتها المحليـة والدوليـة، وتحسـين

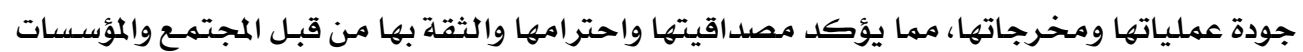

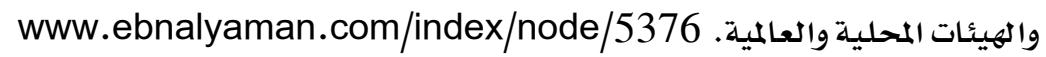

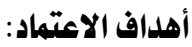

إن الهدف الرئيسي من تطبيق نظام الاعتماد يِّ التعليم هو ضمان جودة العملية التعليميـة،

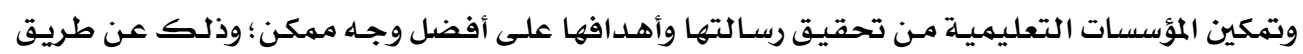

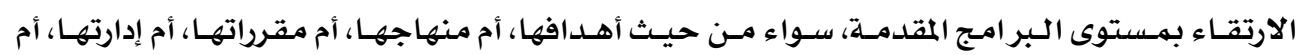

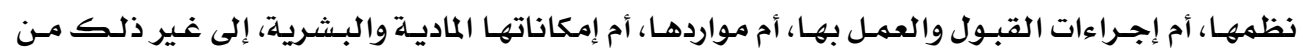

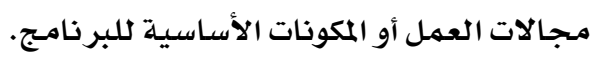

www.ebnalyaman.com/index/node/5376

أنوع الاعتماد:

يمكن تقسيم الاعتماد إلى نوعين (Y، (1)، وهناك من يضيف نوع ثالث إلى النـوعين السابقين

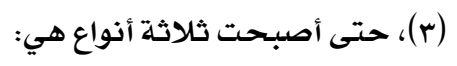

ا. الاعتمـاد المؤسسي (العـام): ويعني أن المؤسسة التعليميـة تحقق معايير معينـة للجـودة التعليميـة،

منها:

- - معايير تخطيطية تخص الحرم الجامعي.

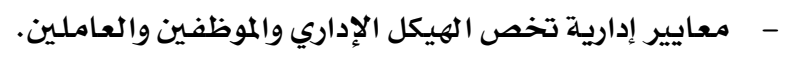


مجلة بحوث التربية النوعية - علد بr - بياير r.

- معايير أكاديهية تخص أعضاء الهيأة التدريسية والبر امـج التعليميلة وعدد الطلاب. - معايير الموارد والخدمات وتخص المختبر ات والمكتبـة والخدمات المختلفة.

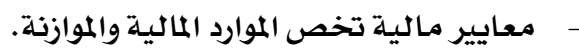
- معايير تخص النشاطات اللاصفية.

Y. الاعتمـاد المهني: ويقصد بـه الاعتمـاد مـن الجهـة المسئولة عن الاعتمـاد المهني المتخحصص، والجهـة

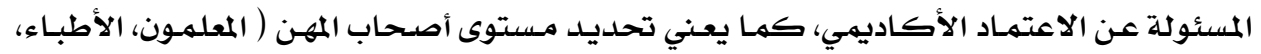

$$
\text { المهندسون...إلخ) . }
$$

ويمكن تعريـف الاعتمـاد المهـني بأنـه : "منظومسة متكاملـة، تهـدف إلى ضـمان إعداد أصسحاب

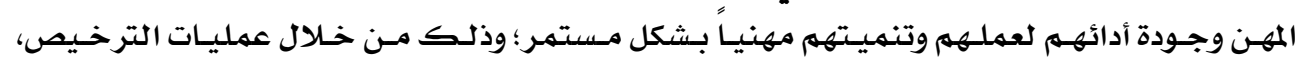

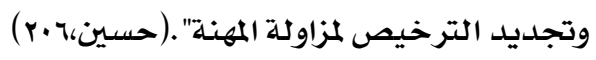

r. وهنالك من يـيف نوع ثالث وهو: الاعتمـاد البر امجسي أو التخصصي، ويقصد بـه تقيـيهم البر امـج

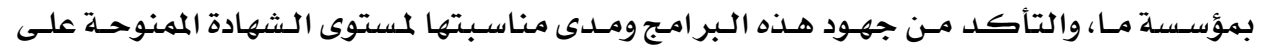

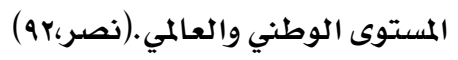

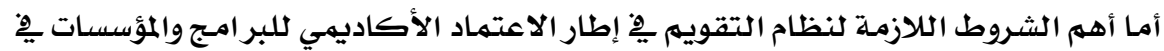

$$
\text { التعليه العالي تتمثل يخ عشرة معايير، هي: }
$$

$$
\begin{aligned}
& \text { r - العمليـة التعليهية. } \\
& \text { ع - المنهج. } \\
& \text { 7 - الجهة الإداريـة. } \\
& \text { ^ - قيادة المؤسسـة. } \\
& \text { • }
\end{aligned}
$$

$$
\begin{aligned}
& \text { I - أهداف المؤسسة وأغراضها . } \\
& \text { r - إنجازات المؤسسـة. } \\
& \text { ه - مـرافق المؤسسة. } \\
& \text { - V الإدارة المالية. } \\
& 9 \text { - العلاقات الخارجية. }
\end{aligned}
$$

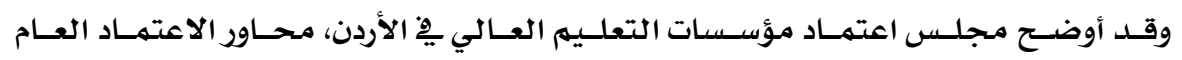

$$
\text { للجامعات وصنفها إلى المحاور الآتيـة: }
$$

$$
\begin{aligned}
& \text { ץ. الهيأة التدريسيـة. } \\
& \text { ع. المختبر ات. }
\end{aligned}
$$$$
\text { ا ـ التنظيم الإداري والأكاديهي. }
$$$$
\text { م. المباني والمرافق الأكاديهية. }
$$

$$
\text { 7. }
$$

ه . الأجهزة والتجهيزات والوسـائل التعليميـة.

^. المرافق العامـة والخاصدة.(أبوالشعر،2)

$$
\text { V. القبول والتسجيل. }
$$

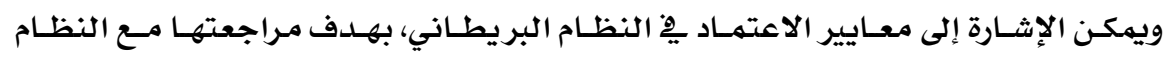

ب.استقلالية الجامعة عن الجههة المالكة. د. تأمـين هيكل تنظيهي مـترابط.
أ .تأمـين بيئـة تعليميـة مناسبـة. ج.ضمان السيولية المالية. هـ · وجود نظام لضمان الجودة. 
و. تأمسين تطوير المناهج التعليمية وأساليب التقييه بمشاركة الهيئة التعليمية.

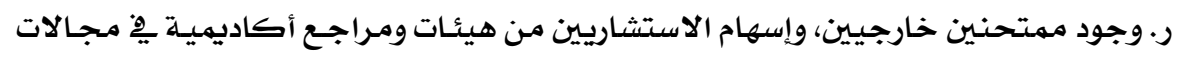

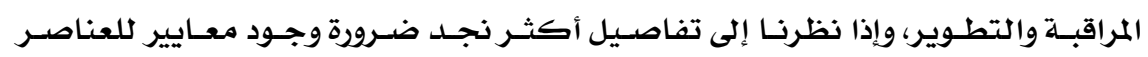

$$
\begin{aligned}
& \text { r r تحقيق الأهداف التعليمية. } \\
& \text { ع ـ التقييم المستمـر للبر امـج. } \\
& \text { 1. طرق التقييم. }
\end{aligned}
$$

$$
\text { هـ ـ ـ شروية وأساليب التعليه الشهادات. }
$$

\section{العلاقة بين الاعتماد وضمان الجودة:}

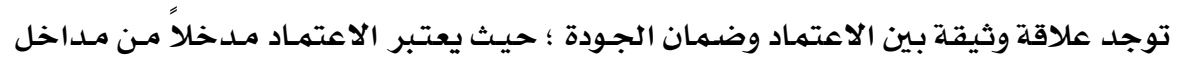

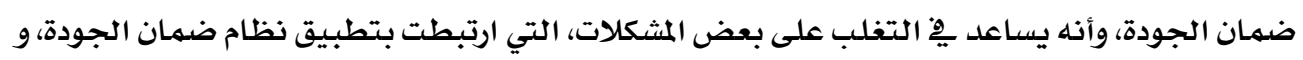

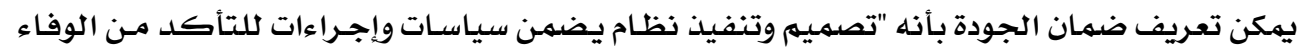

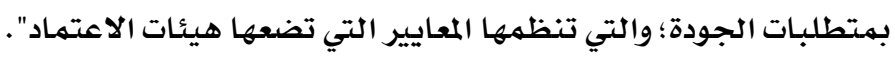

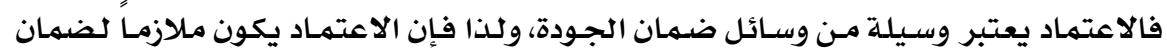

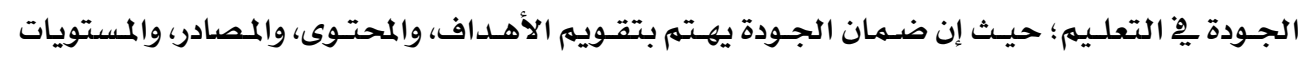

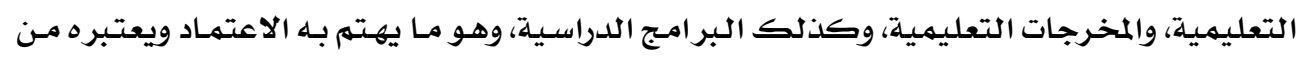

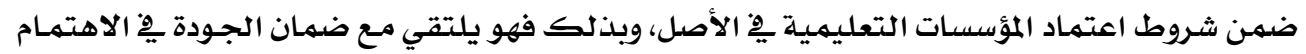

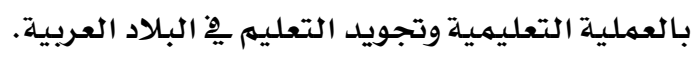

\section{ويمكن تحقيق ضمان الجودة بطريقتين، هما:}

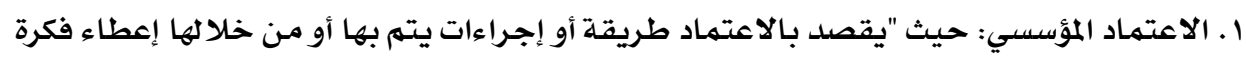

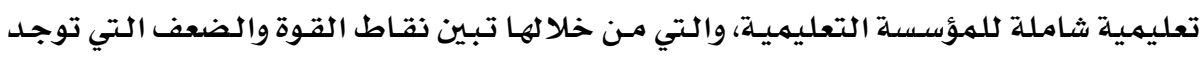

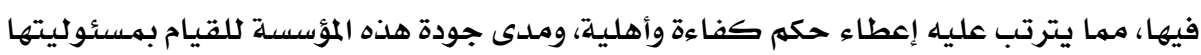

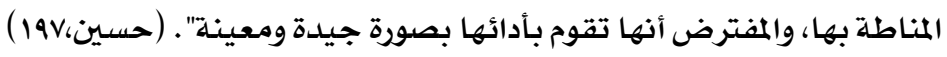

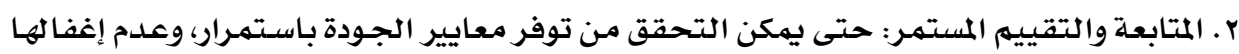

$$
\text { حتى لا يترتب عليه مخالفات لمبادئ الجودة. }
$$

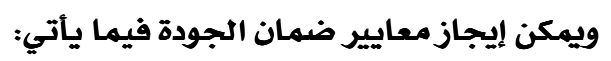

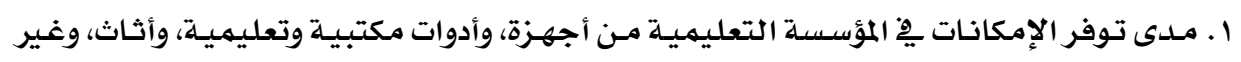

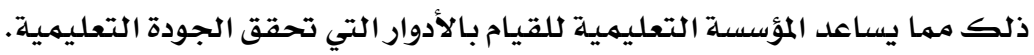

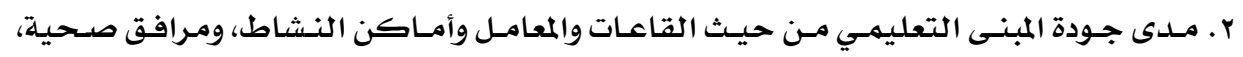

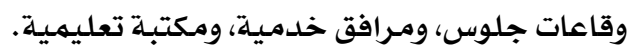

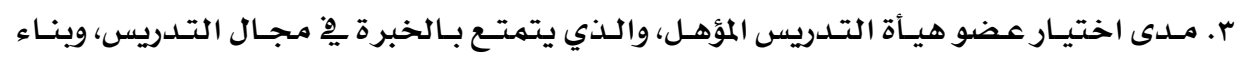

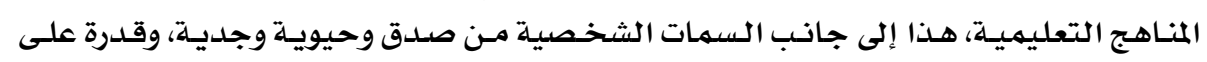

التواصل مـع طلابه، وغير ذلك مما ينعكس على جودة التعليهم. 


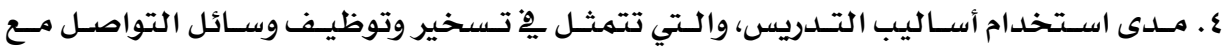

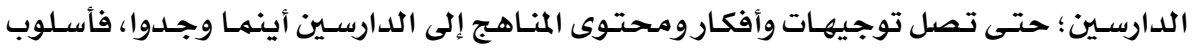

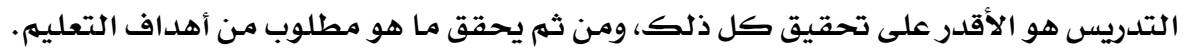

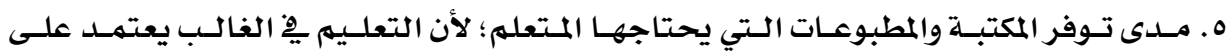

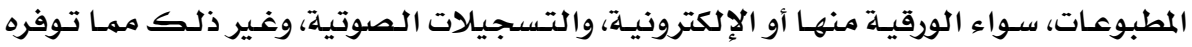
المؤسسة، من أجل تحقيق فلسفة التعليه.

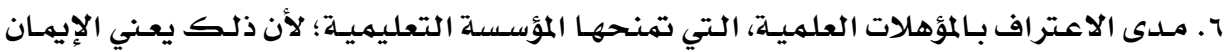

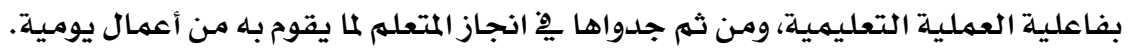

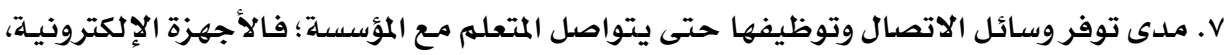

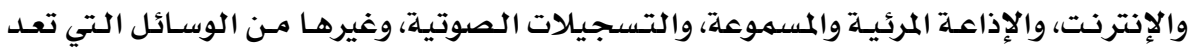

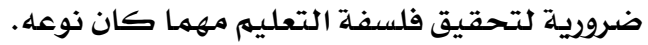

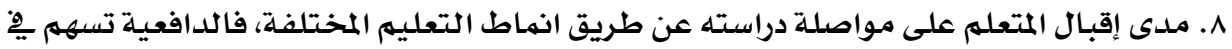

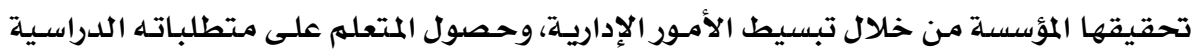

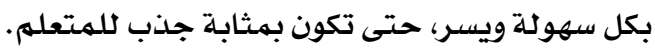

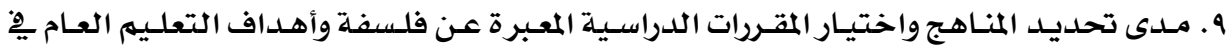

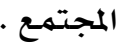

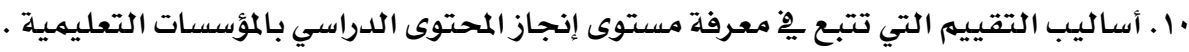

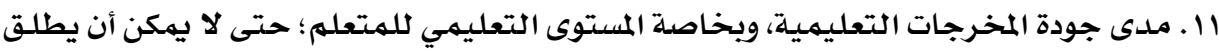

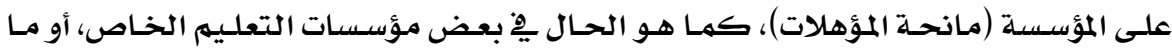
يسمى يٌْ ليبيا بالتعليه التشاروكي.

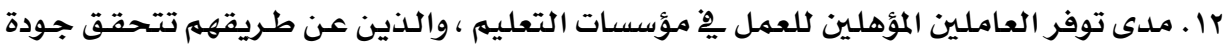

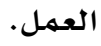

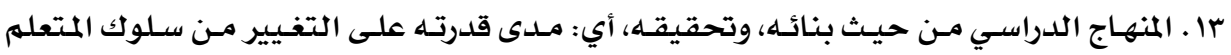
حسب المستهدف من العملية التعليمية... ع ا ـ مدى الأخذ بفلسفة وأهداف التعليم ، الذي يسعى إلى تحقيق النمو الشامل للمتعلم (عقليا،

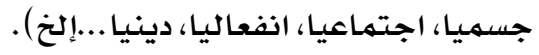

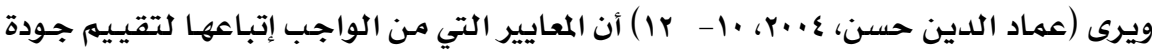

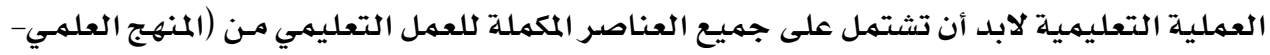

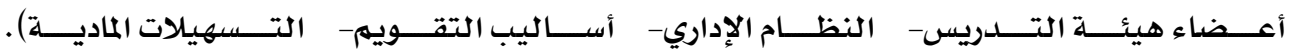

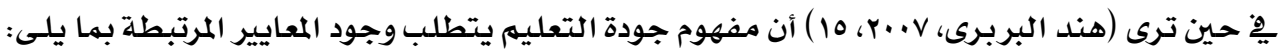

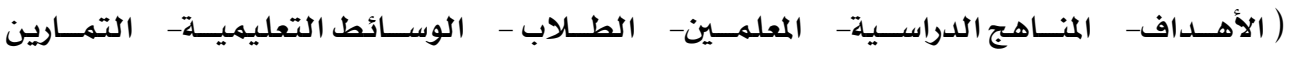
والتدريبات- الاختبارات والامتحانات).

http://nokhba-kw.com/vb/showthread.php?t=2199 
ومن خلال ما تقدم يمكن إجمال تلك المفردات يِّ المقومات الآتية:

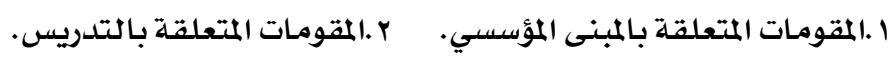

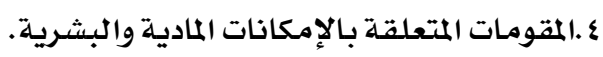

r.المقومات المتعلقة بالمتعلهم.

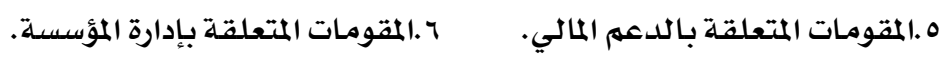

V المقومات المتعلقة بسياسة البلد التعليمية.

إن الحديث عن جودة التعليهم يتطلب التطرق إلى مدلى تحقيق المؤسسة التعليميـة لأهدافها،

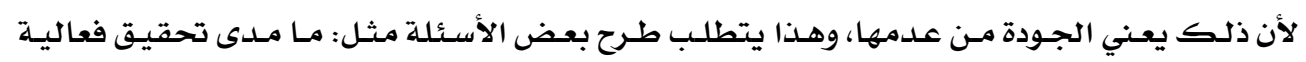

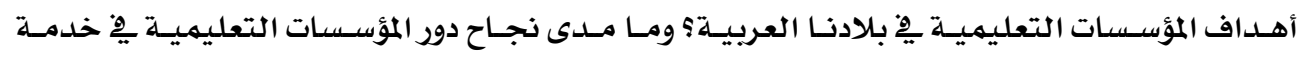
المجتمـع وتنـميتهـ أموات

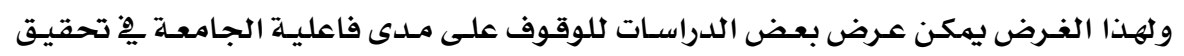

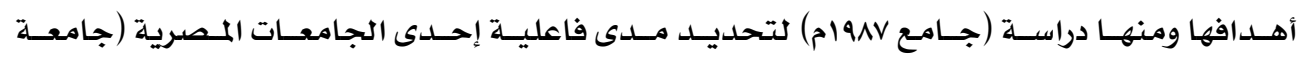

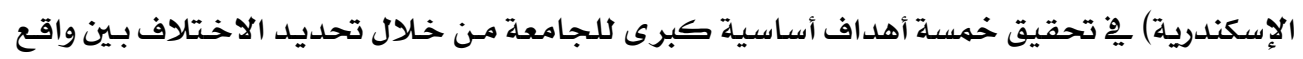

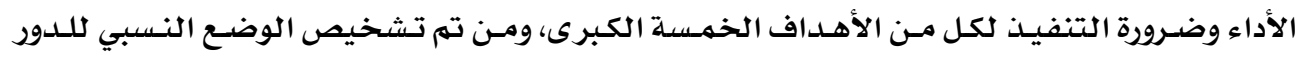

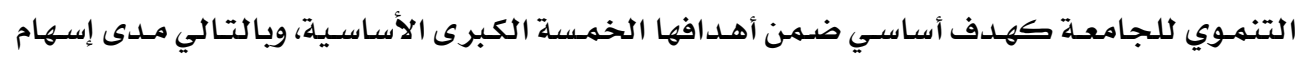
الجامعة يِ عملية التنمية الوطنية الشاملة.

وبعد استطلاع أراء عينـة الدراسـة مـن أعضاء هيئسة التـدريس يِّ الجامعـة التي كـان عددها

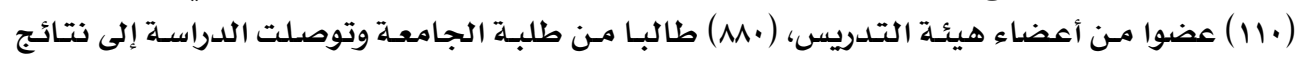
عديدة من أبرزها ما يأتي:

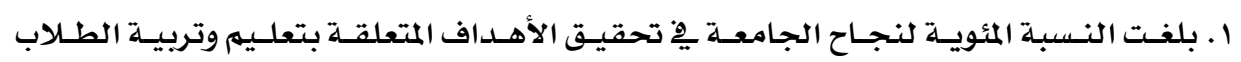

. $(\%, \varepsilon \wedge, \varepsilon)$

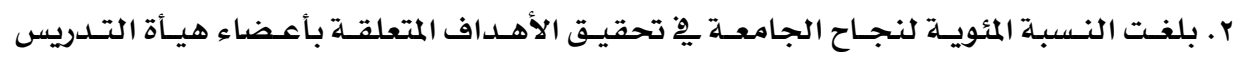

. $(\% £ 9, Y)$

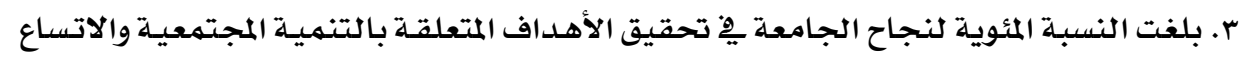

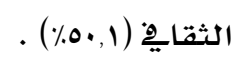

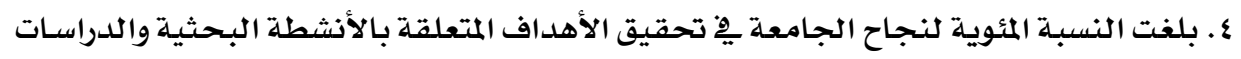

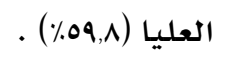

ه . بلغت النسبة المئوية لنجاح الجامعة يِّ تحقيق الأهداف المتعلقة بالإدارة الجامعية (ع,به٪) ) .

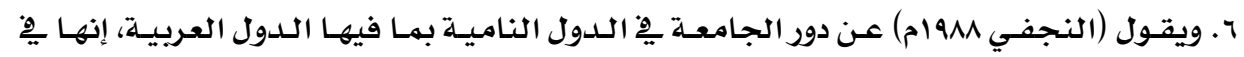

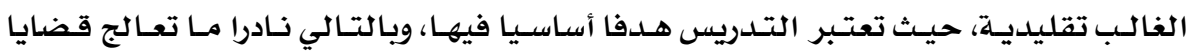

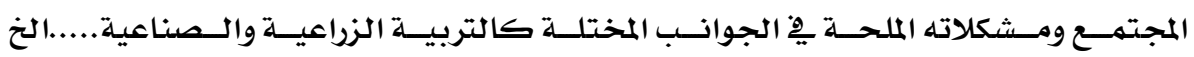

(زيتون، (المجتوع) 


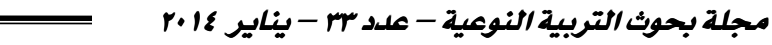

V. وِِّ إحـدى الدراسـات أكـد (09٪) مـن المبحـوثين على ضـرورة تقـويم وتطـوير المنـاهج الدراسـية

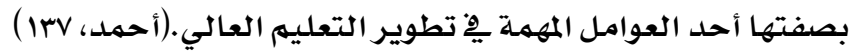

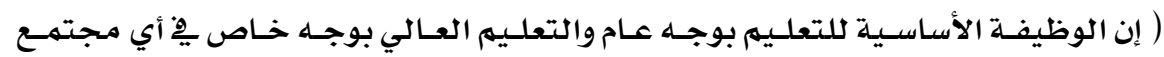

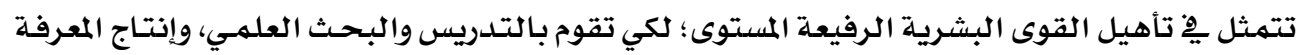

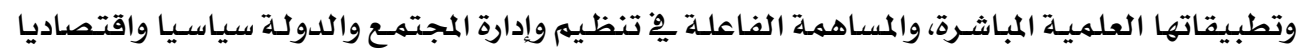

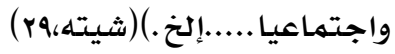

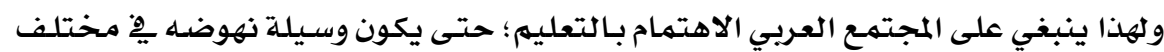

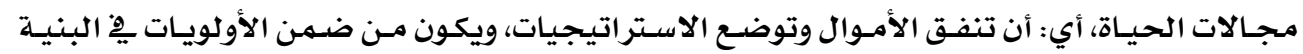

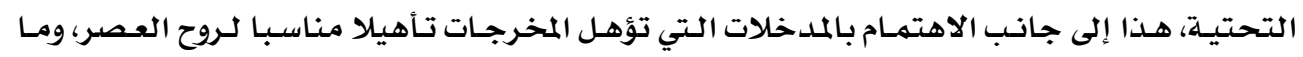

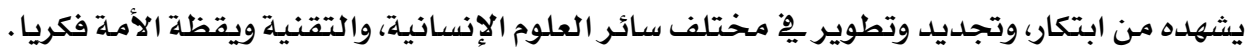
ومما سبق يمكن تحديد الآلية التي تطبق بها معاير الجودة ِِ المؤسسات التعليمية والمتمثلة

فيما يأتي:

r إجراءات تتعلق بالحكومـة.

ا ب إجراءات تتعلق بسيادة الدولة.

r. r.اجراءات تتعلق بالوزارة المختصدة.

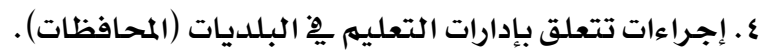

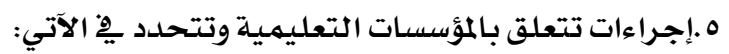

ب. ب. الإدارة المدرسية.

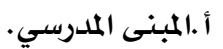

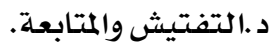

ج. أعضاء هيأة التدريس. أمبنس.

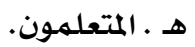

ويمكن توضيح هذه الإجراءات على النحو الآتي:

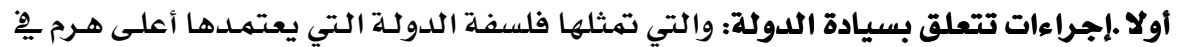

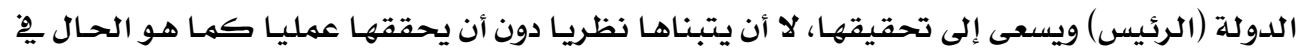

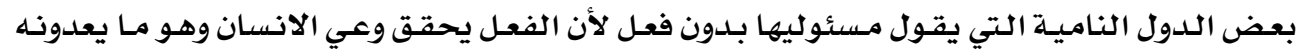

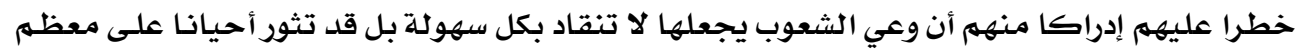

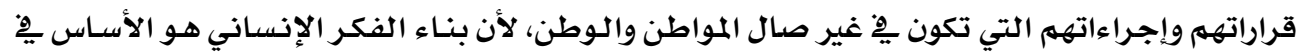

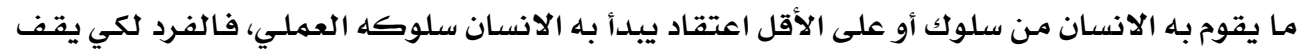

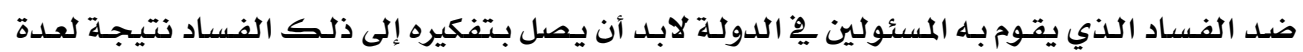

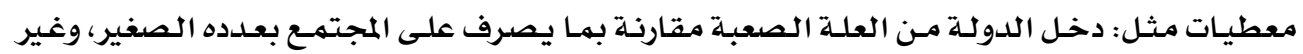

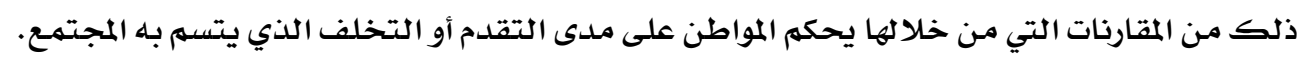

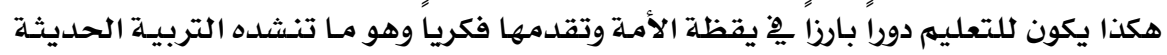

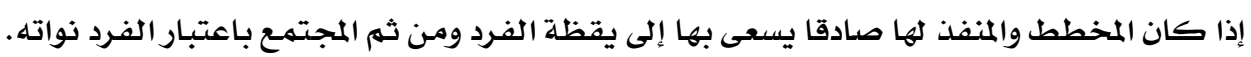




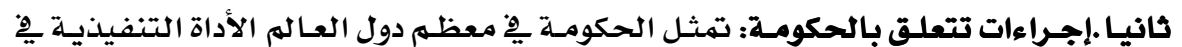

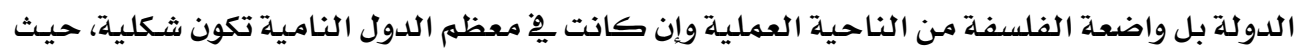

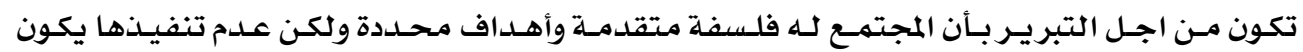

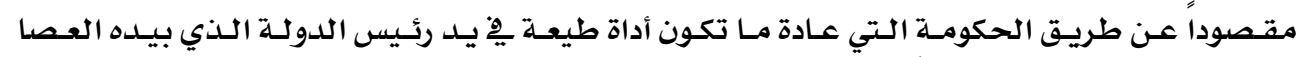

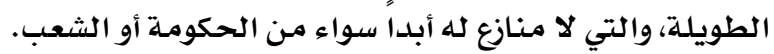

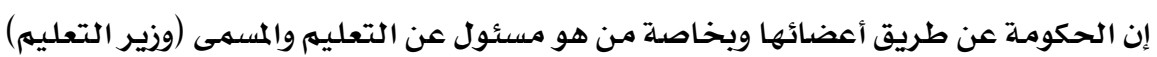

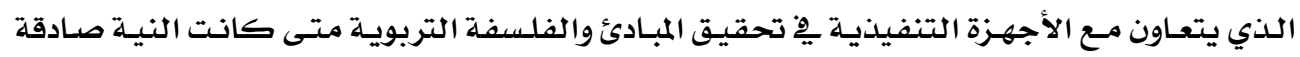

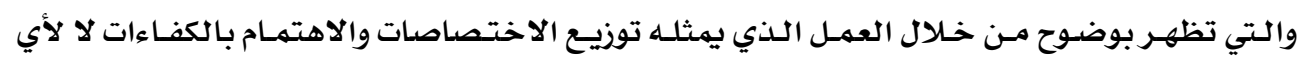

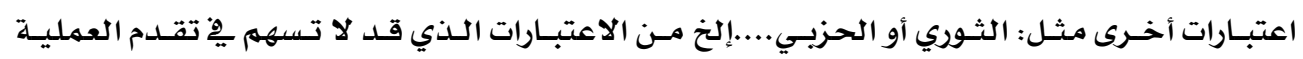
التعليمية وتطورها، بل قد تعيقها أندان أحيانا.

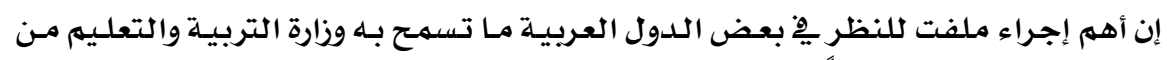

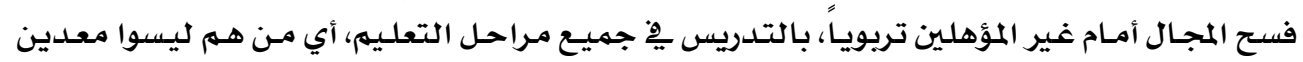

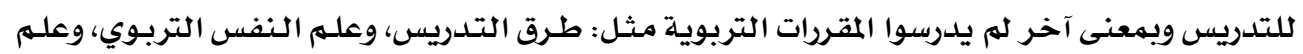

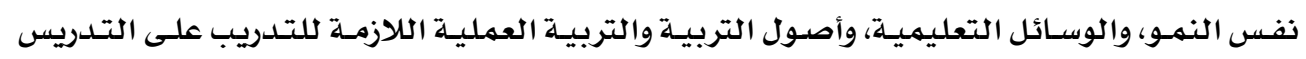

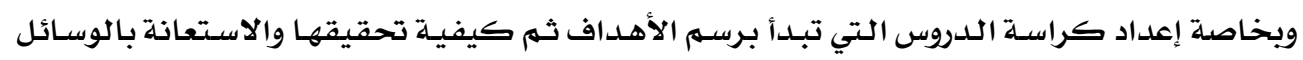

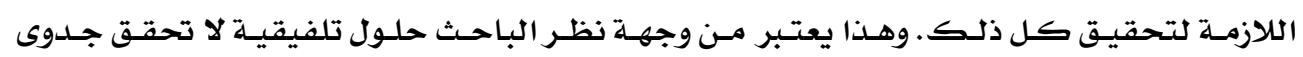
العملية التعليمية بل خيانة فيها.

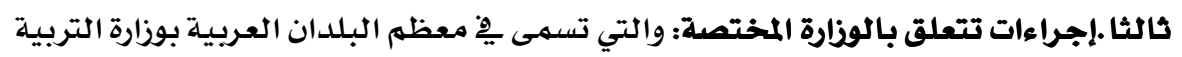

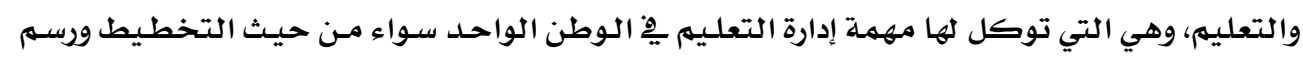

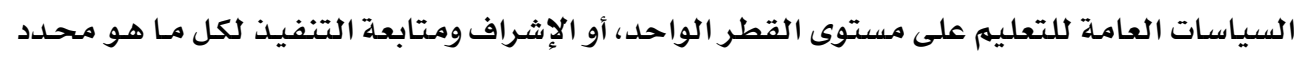

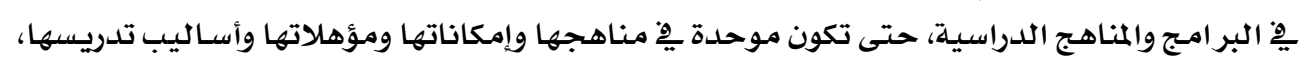

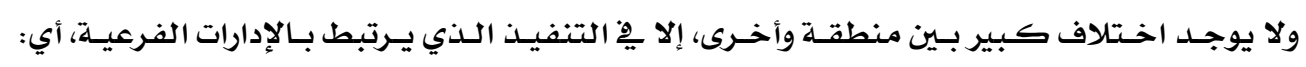

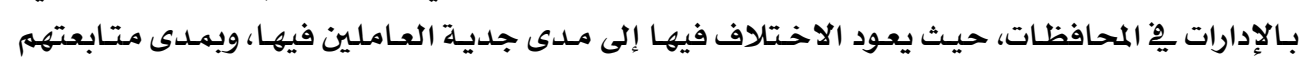

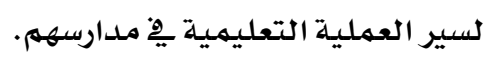

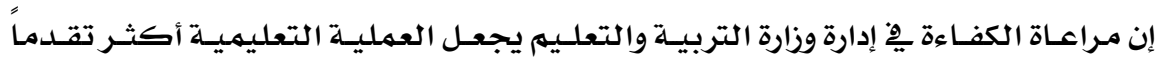

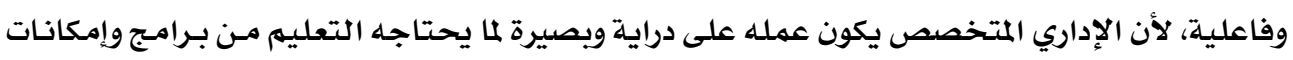

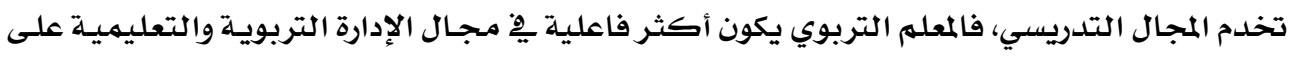

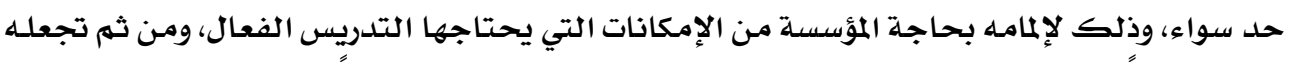

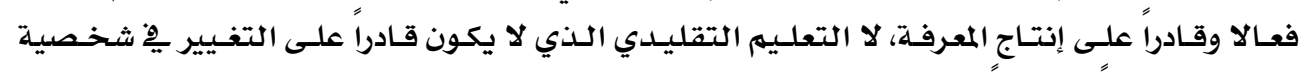
المتعلم سلوكياً ومعرفياً.

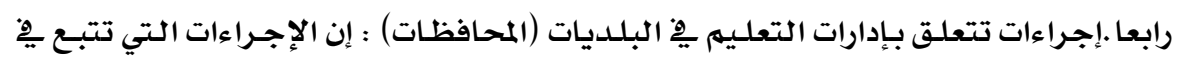

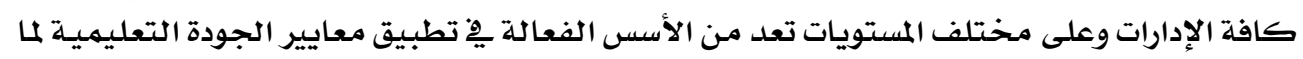


تضفيه على العمل من شفافية وجدية ورفحاً للمحسوبية، وغير ذلك مـن الأخطاء التي تتؤدي إلى قلـة

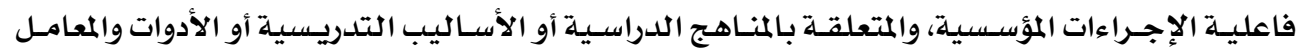
الفنية...إلخ، مما تحتاجه العملية التعليمية الموسية حتى تكون فعالية.

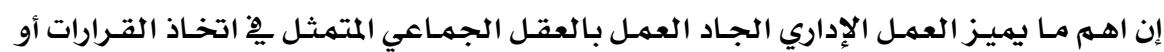

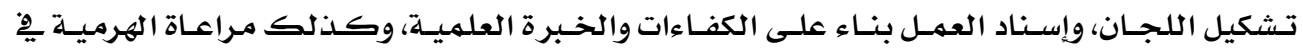

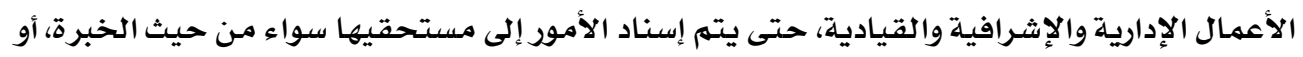

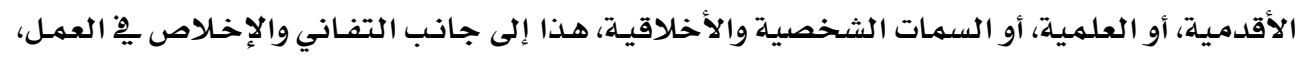

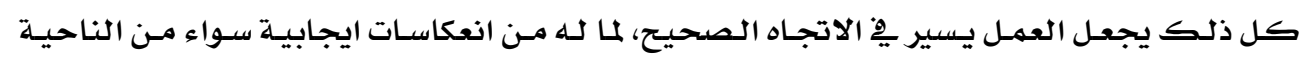
العلمية أو النفسية والسلوكية.

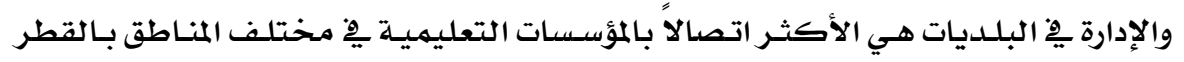

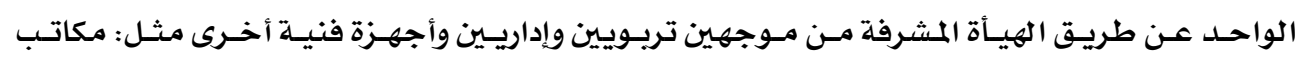

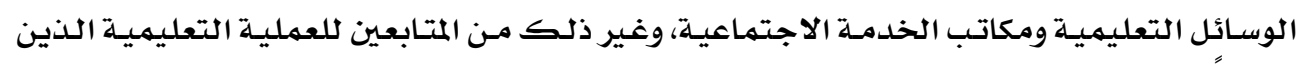

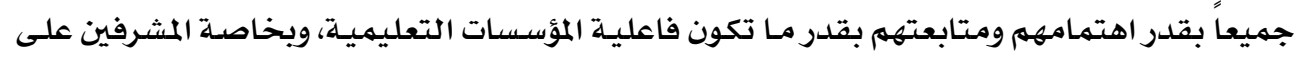

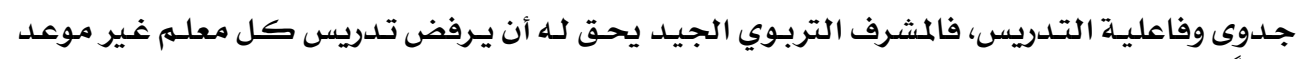

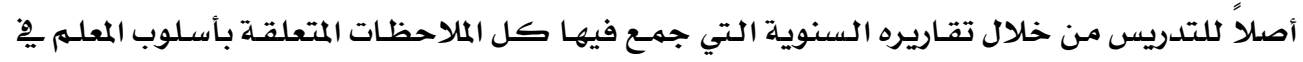

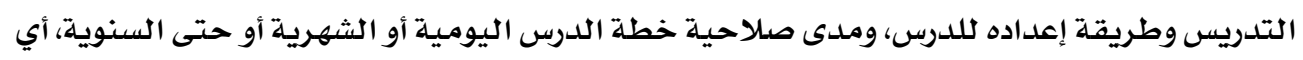

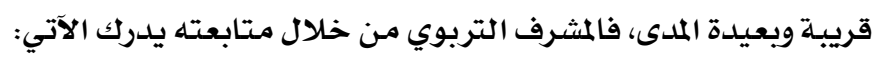

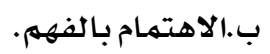
أ . تضمين الخطة للأهداف، ومنها الأهداف السلوكية.

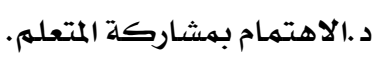
ج.استخدام المعلهم لتكنولوجيا التعليه.

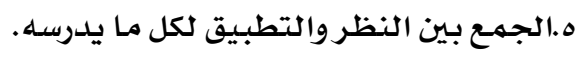

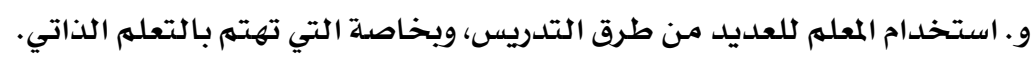

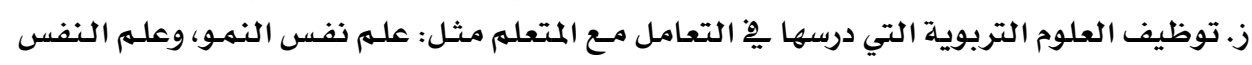

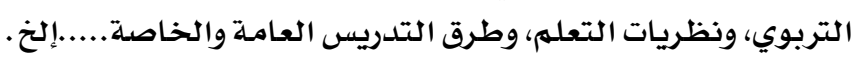

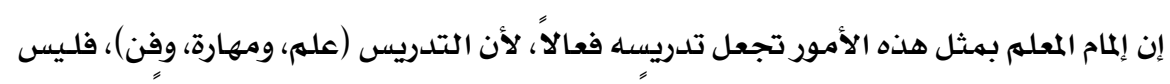

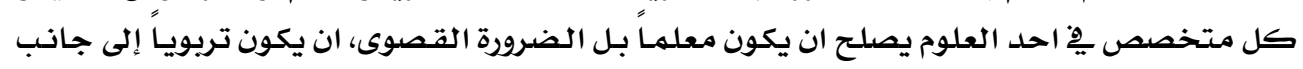

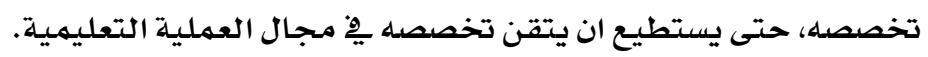

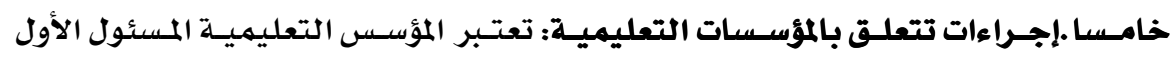

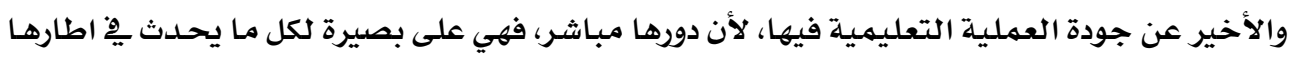

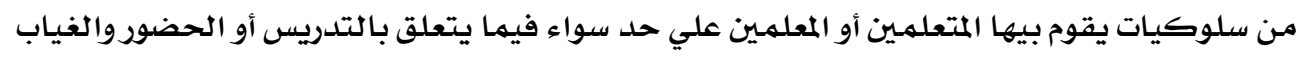

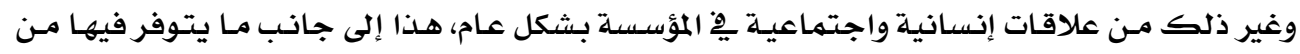

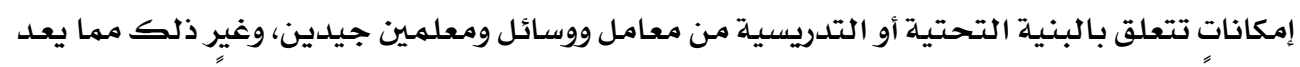

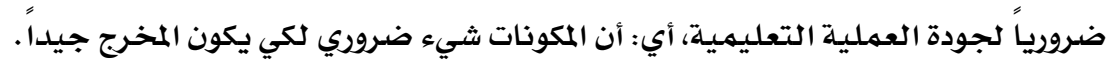


ومن المدخلات المهمـة يِ المؤسسة التعليمية ما يأتي:

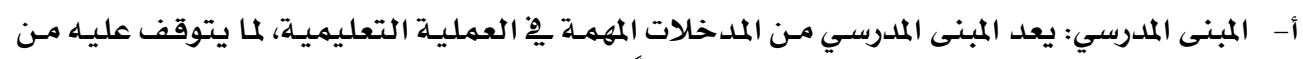

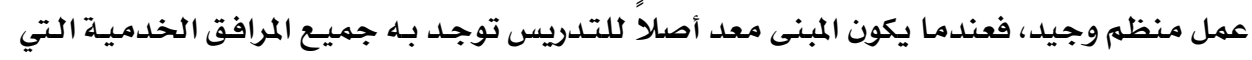

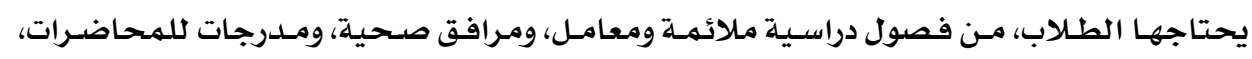

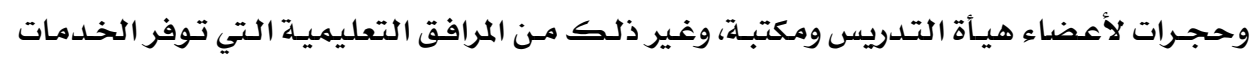

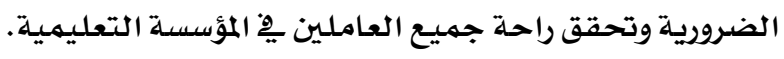

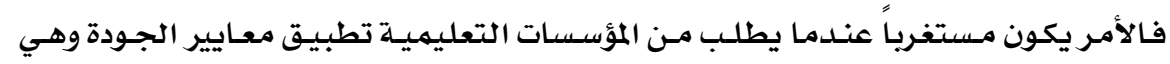

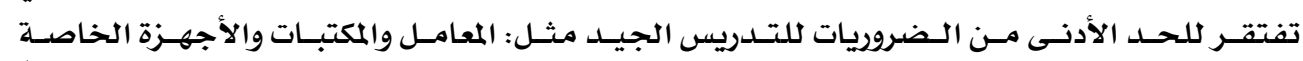

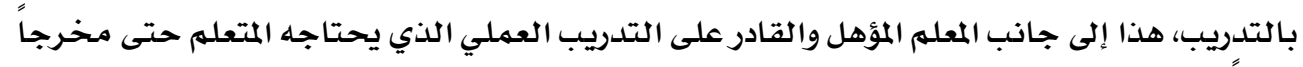
جيداً.

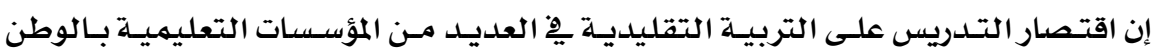

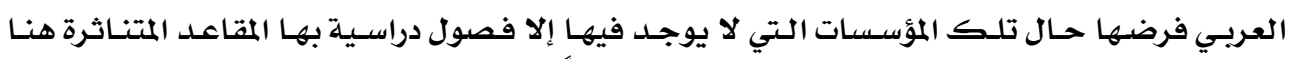

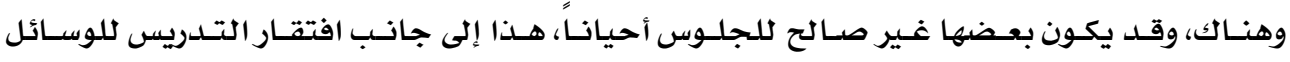

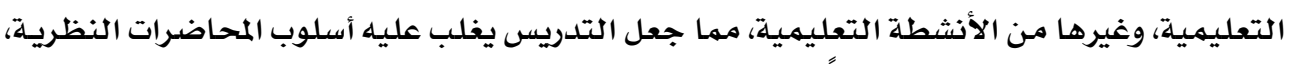

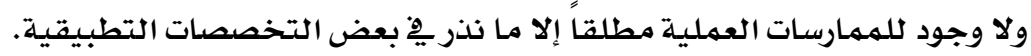

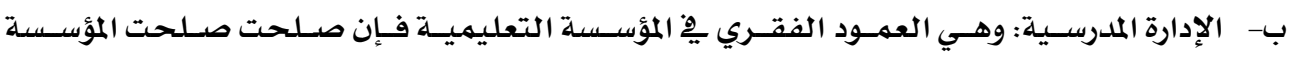

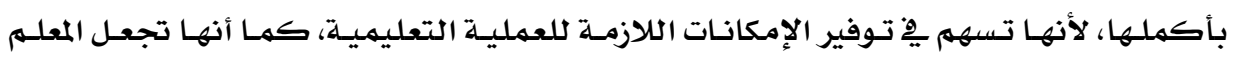

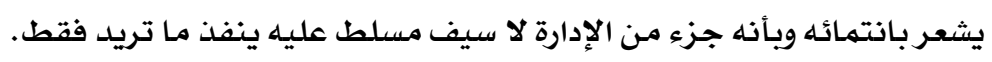

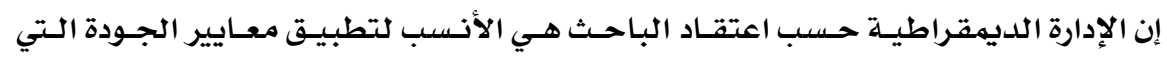

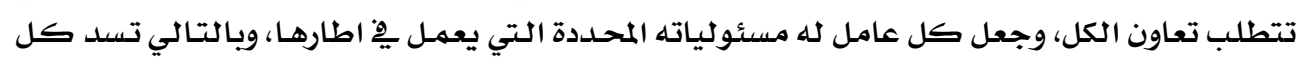

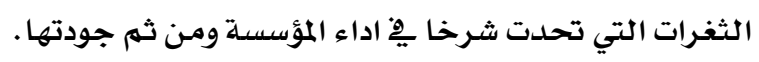

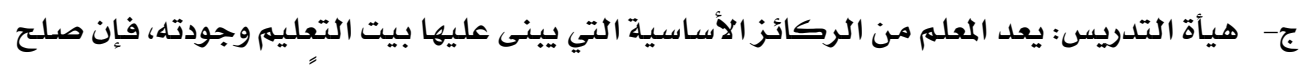

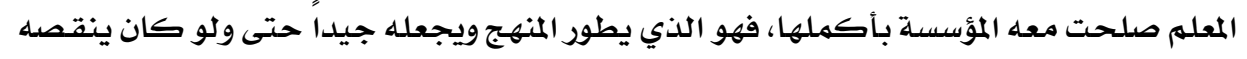

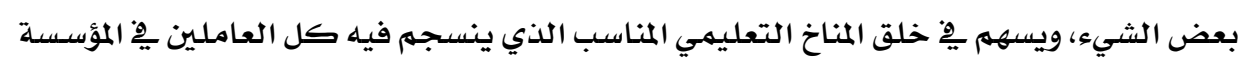

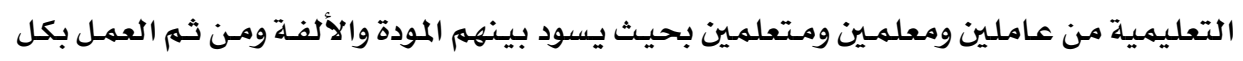

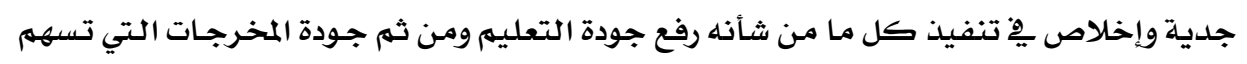
مِّف تنمية الوطن العربي الكبير.

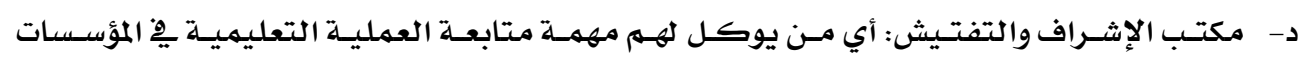

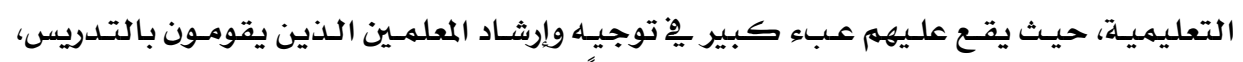

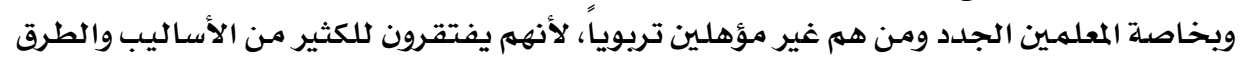

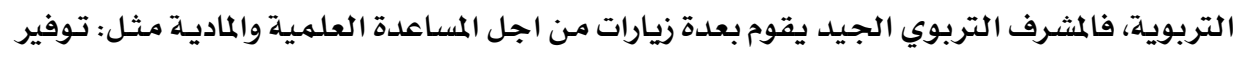

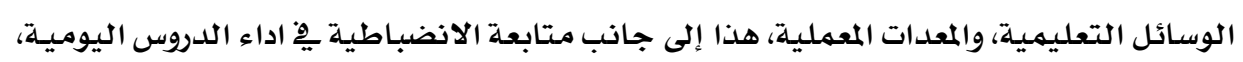




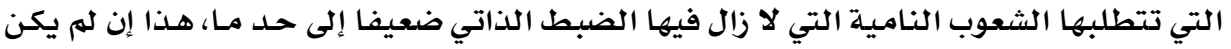

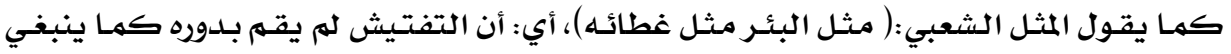

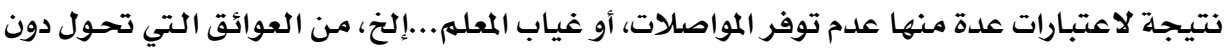

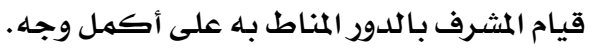

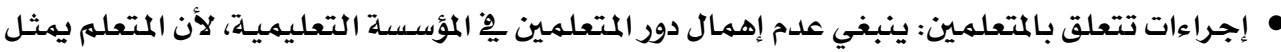

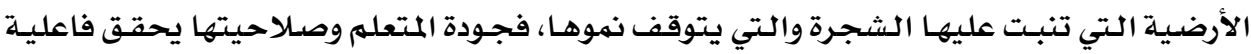

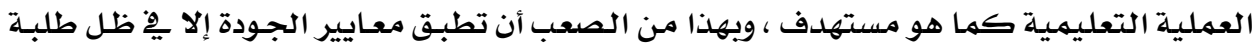

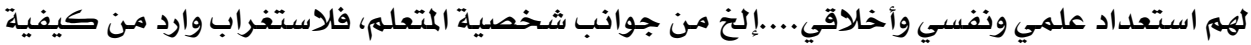

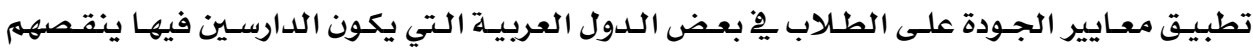

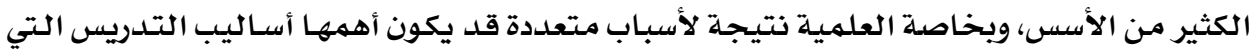

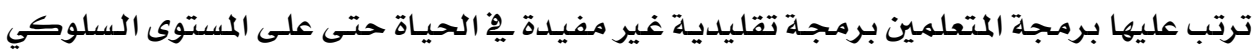

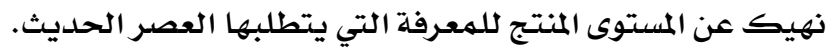

\section{إن المؤسسة التعليمية ركيزتها المتعلم الذي ينبغي أن يتحلى بالآتي:}

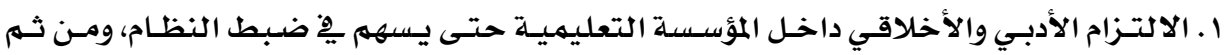

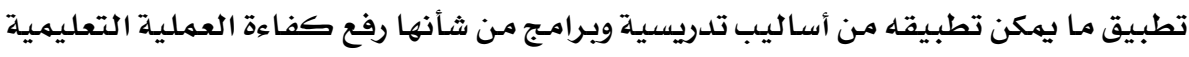

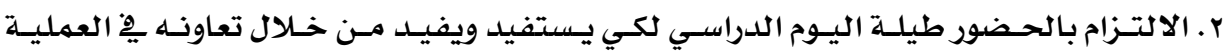

$$
\text { التعليمية. }
$$

ب. المشاركة ِِِ كل الأنشطة التي تقوم بها المؤسسة التعليميـة سواء داخل القاعـة الدراسيـة أم

$$
\text { خارجها. }
$$

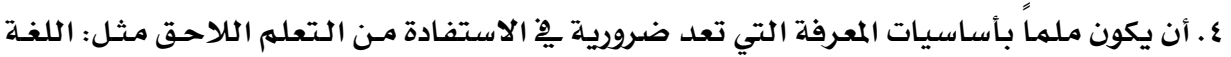

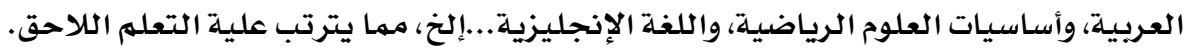

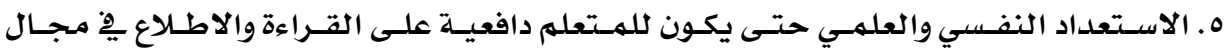

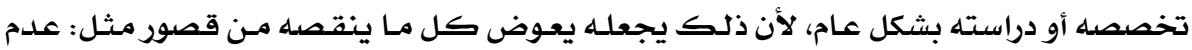

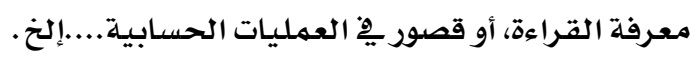

\section{أما على مستوى المدرسة، فإن تطبيق برنامج الجودة يمر بالخطوات الآتية،}

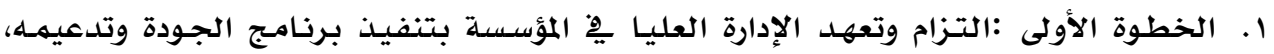

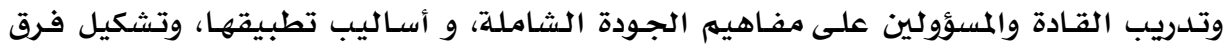

$$
\text { تحسين وتوكيد الجودة. }
$$

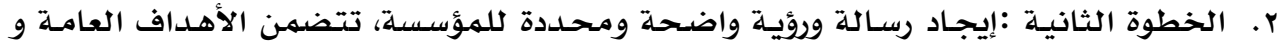

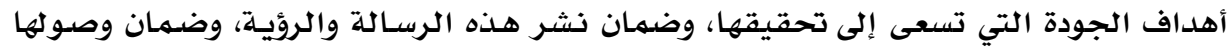
لجميع أفرادها. 
r. الخطوة الثالثة :تشكيل مجلس للجودة يضم ِِّ عضويته المديرين التنفيذيين يِّ المؤسسة

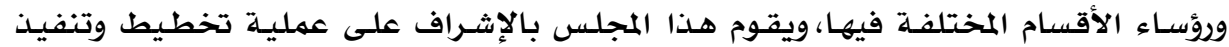
وتقويم برنامـج الجودة.

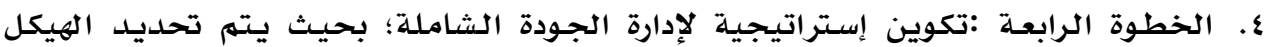

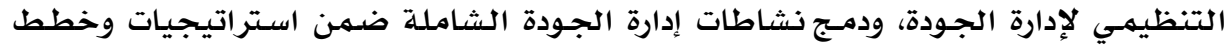

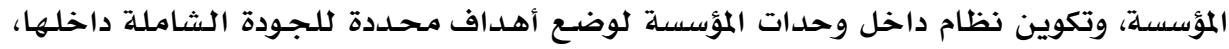

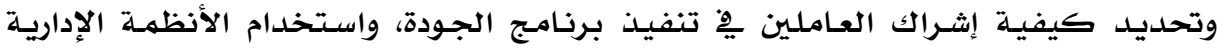

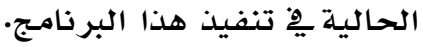

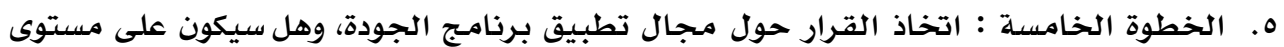

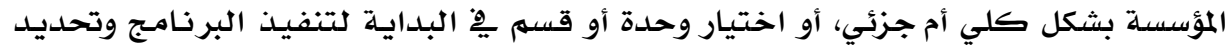
مدى الاستعداد للتغيير والتنفيذ.

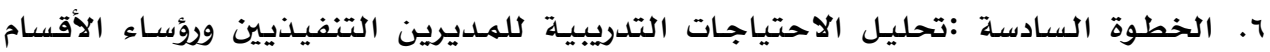

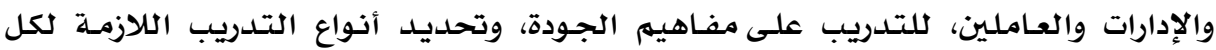

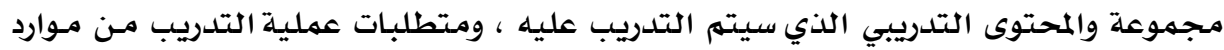
بشرية ومادية وتنظيمية.

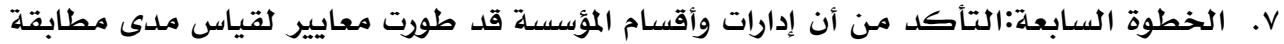

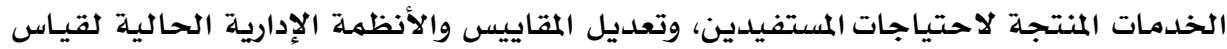
درجة تلبية هذه الاحتياجات.

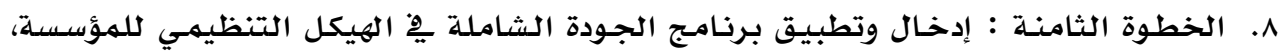

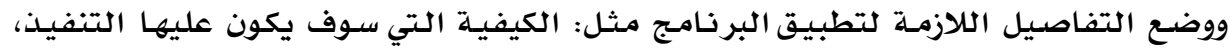

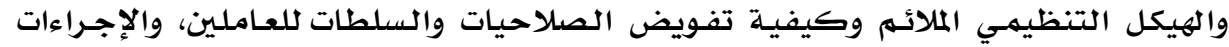

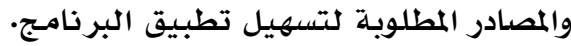

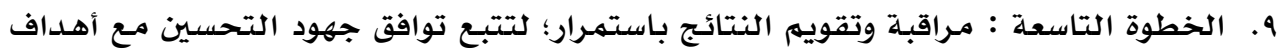

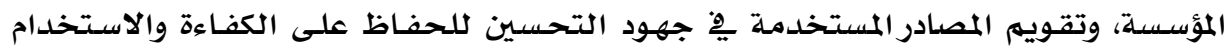
الأمثل لهذه المصادر.

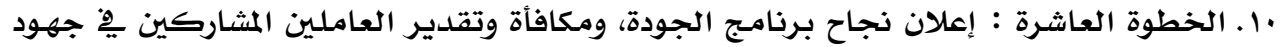

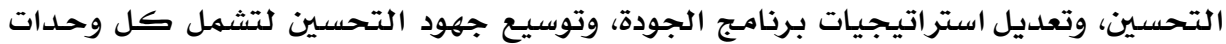
وأقسام وإدارات المؤسسة. mhtml:file://E : خطوات تطبيق الجودة mht!http://www.qu.edu.sa/Default.aspx?tabid=5304 


$$
\text { ت = التعليهم }
$$

رسهم توضيحي لهيكلة الاتصال التعليهي

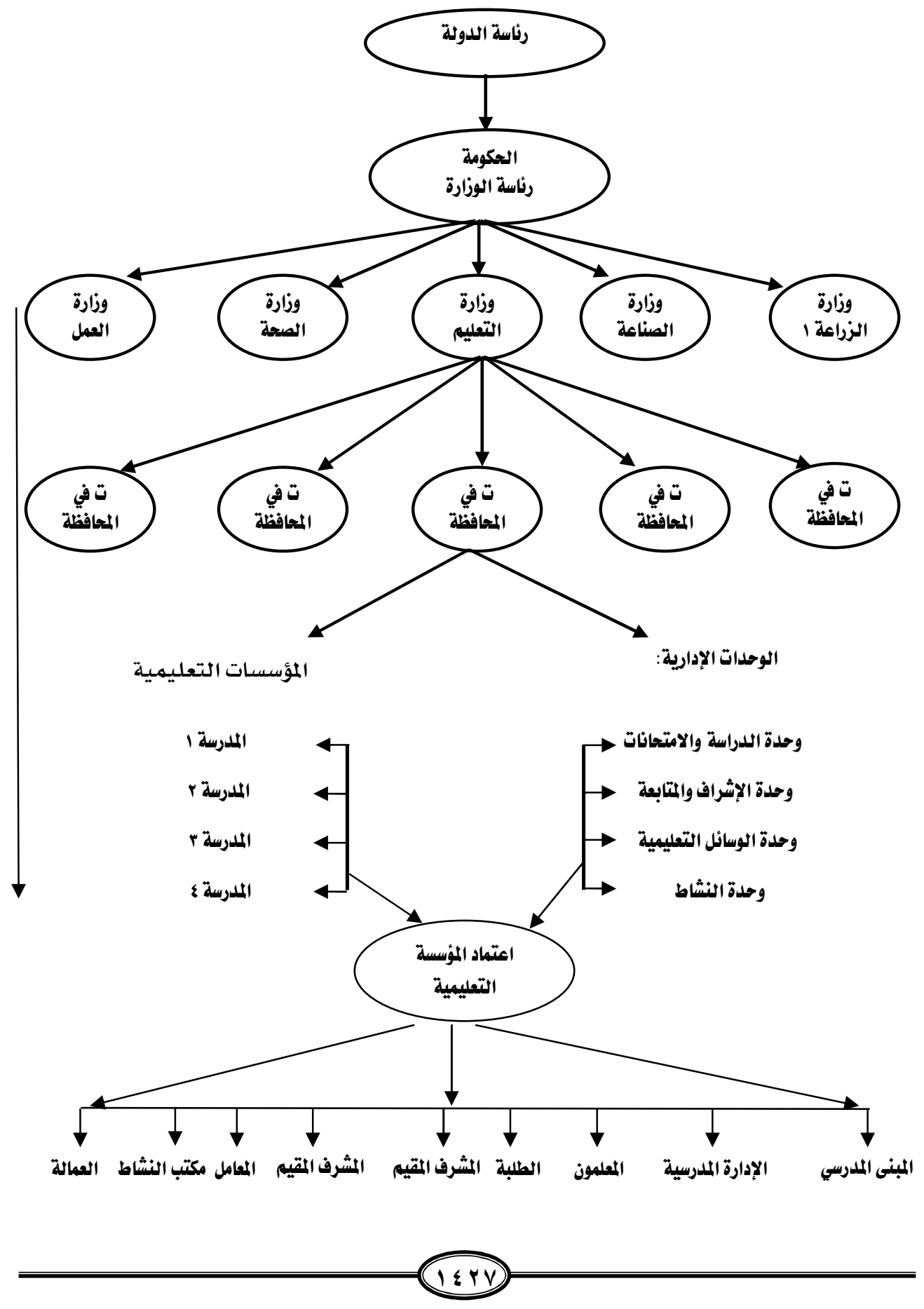




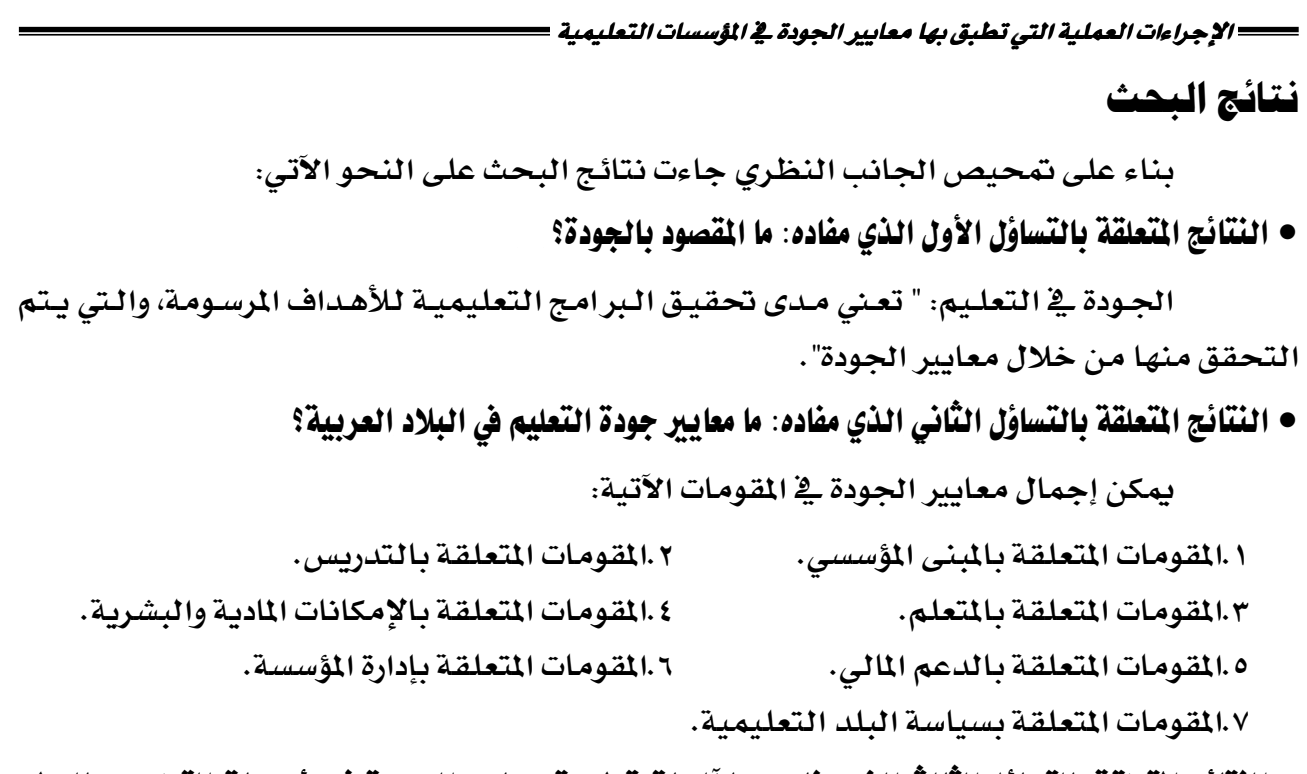

• النتائج المتعلقة بالتساؤل الثالث الذي مفاده: مـا آليـات تطبيـق معايير الجــودة في مؤسسات التعليه بـالوطن العربي؟ يمكن تحديد الآلية التي تطبق بها معاير الجودة يِ المؤسسات التعليمية من خلال ما يأتي:

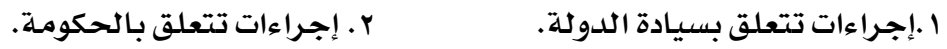

$$
\begin{aligned}
& \text { r.إجراءات تتعلق بالوزارة المختصدة. }
\end{aligned}
$$

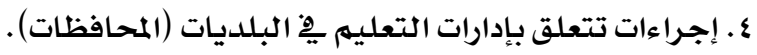

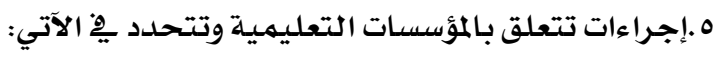

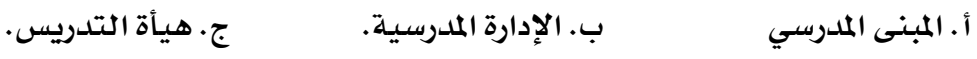

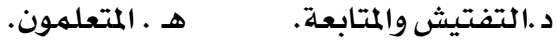

• النتائج المتعلقة بالتساؤل الرابع الذي مفاده: ما التوصيات المتعلقة بآليـة تطبيـق معايير الجـودة في مؤسسات

\section{التعليم بالوطن العربي؟ بالتئ}

$$
\text { بناء على النتائج التي توصل إليها البحث فإن الباحث يوصي بما يأتي: }
$$

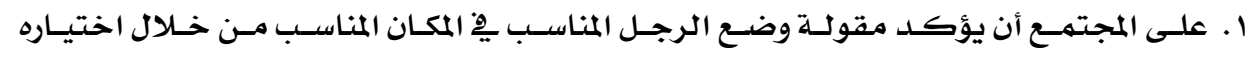

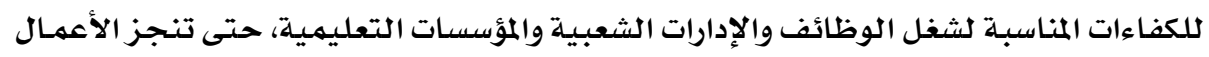

$$
\text { كما ينبغي. }
$$

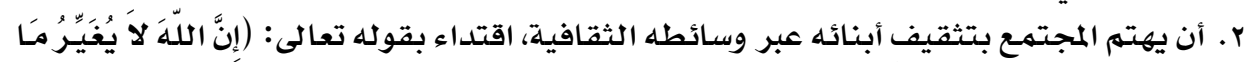

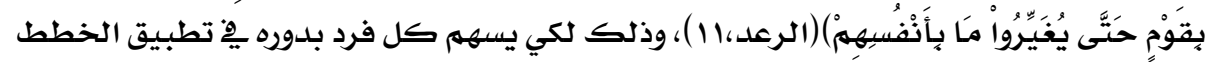

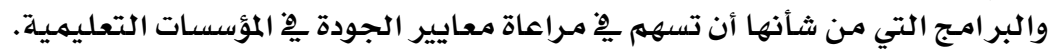


مجلة بحوث التربية النوعية - علدد بr - بيناير 18

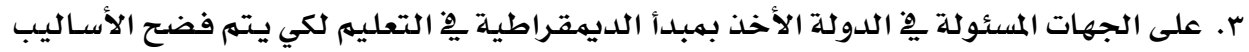

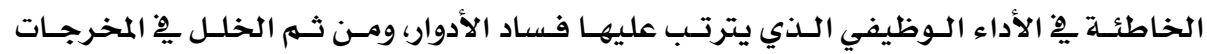

التعليمة . الخمائة

ع. ان تخصص خزانة الدولة الأموال الطائل لصالح التعليم حتى يهكن توفير البنية التحتية التي

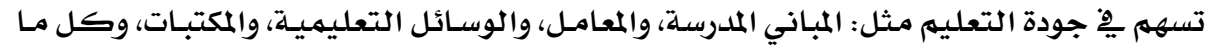
يتعلق بالأنشطة التعليمية.....إلخ.

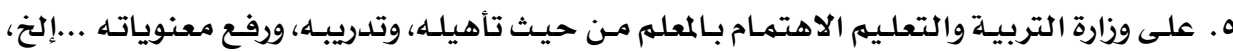

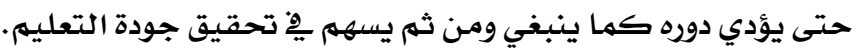

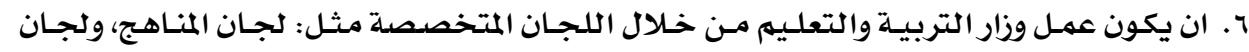

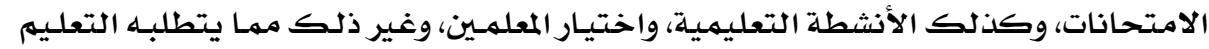

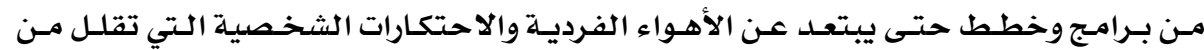
فاعلية التعليم يِّ المؤسسات التعليميلة.

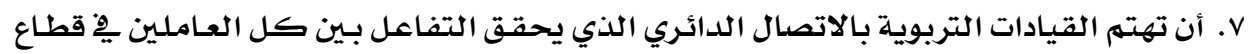
التعليه. الإقتزحات:

مِّوضوء النتائج التي توصل إليها البحث يقترح الباحث ما يأتي: ا ـ إجراء دراسـة ميدانية بغرض معرفة الإمكانات المتوفرة ِيْ المؤسسات التعليمية من مباني، ومعلمـين، ومكتبات، ومعامل، ووسائل تعليمية.

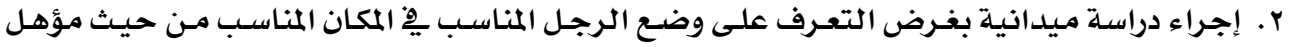

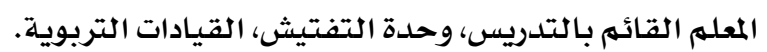

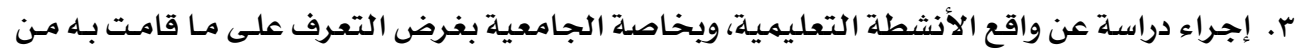

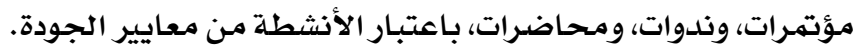

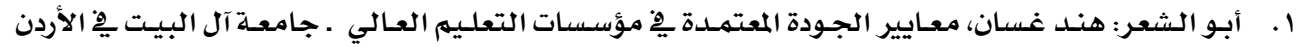

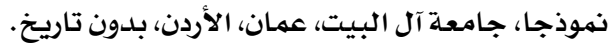

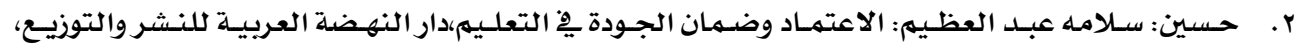

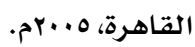

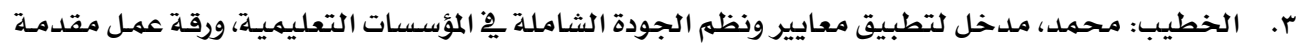

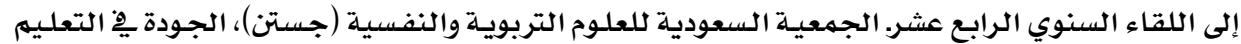

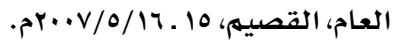

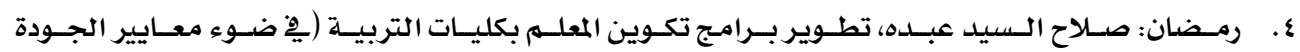

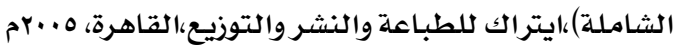




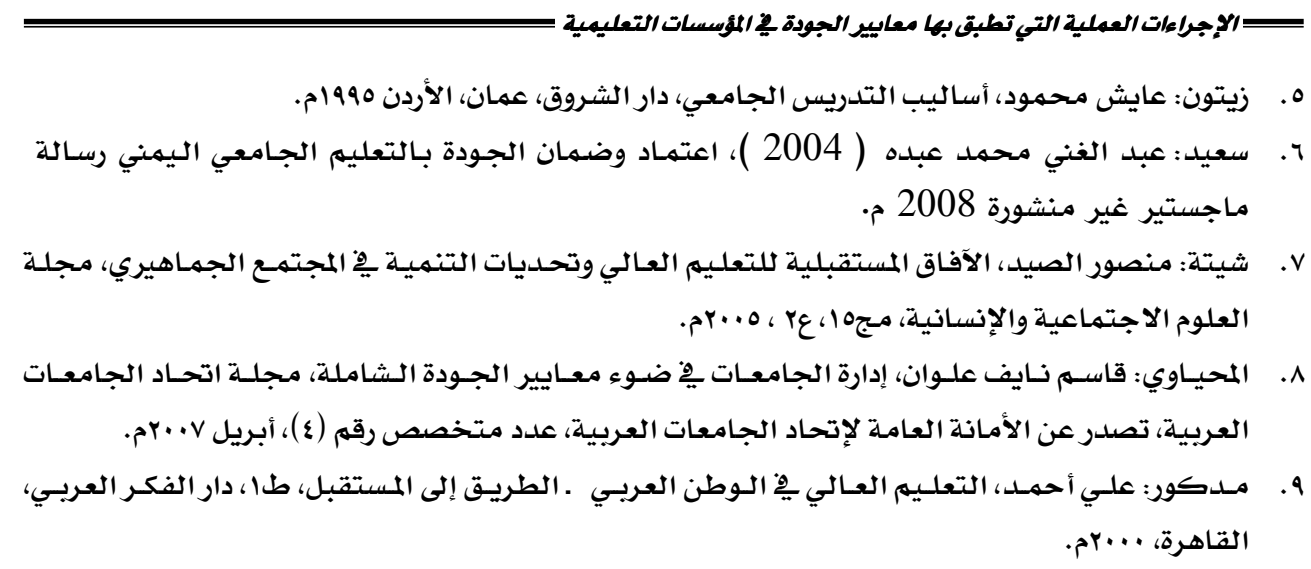

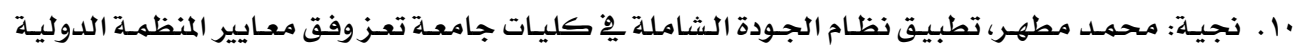
للمواصـفات والمعـايير مـن وجهـة ظـر العمــاء ونـوابهم ورؤسـاء الاقسـام، كليـة التربيـة، جامعـة تعـز، بـــون

الـ نصر: نوال، ضمان الجودة والاعتماد لمؤسسات إعداد المعلمـين ـ تجارب دولية، المؤتتـر العلهي السنوي (العربي

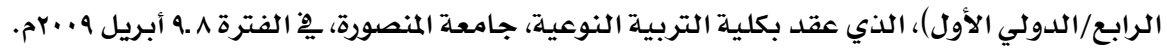

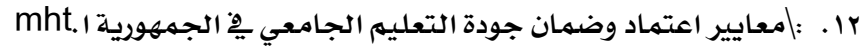

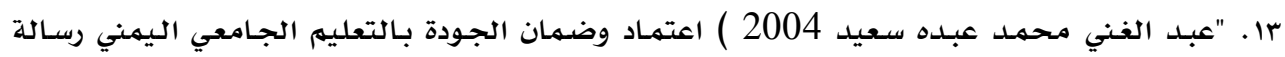
ماجستير غير منشورة 2008 م". sharia.kuniv.edu.kw/index.php?option=com_content . . - Itemid=252\&id=397\&view=article\& http://nokhba-kw.com/vb/showthread.php?t=2199 . . mhtml:file://E : خطوات تطبيق الجودة 17 www.alzahraa.ibda3.org8/11/2011) . . v 8/11/2011 www.furat.alwehda.gov.sy . ^ www.ebnalyaman.com/index/node/5376 . 19 